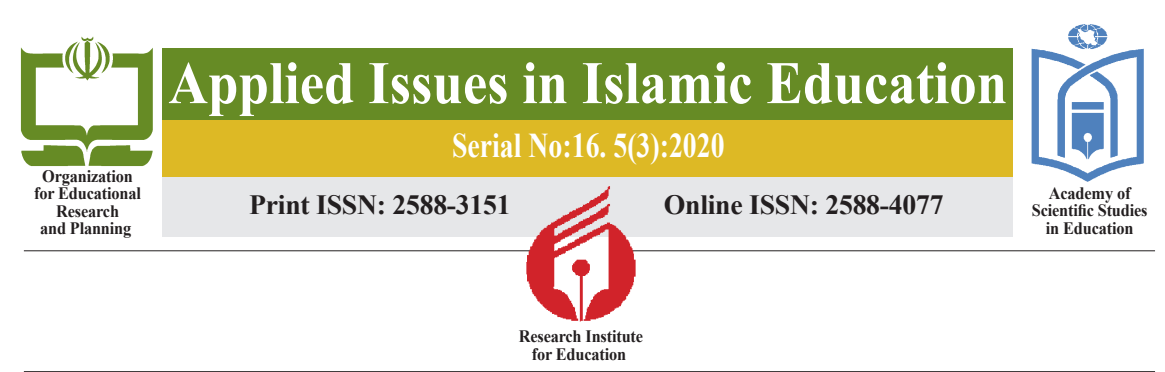

\title{
Providing an Iranian-Islamic Model for a Happy School in the Elementary Education System in Iran
}

Somayyeh Bahramian ${ }^{1}$, Mohammad Ali Nadi ${ }^{2}$, Fariba Karimi ${ }^{3}$

Objective: This study aims to provide an Iranian-Islamic model for a happy school for the elementary education system in Iran through a combined research approach, exploratory-sequential strategy, and tool development model.

- Method: The method of inductive thematic analysis in the qualitative phase and the method of survey research in the quantitative phase were used. In the qualitative phase, the field of study was the Iranian-Islamic sources and texts relating to happiness and, in the quantitative phase, the statistical population of the study was all the principals of the elementary school in the country during this study. In the qualitative phase of the study, the sampling method was purposeful, and in the quantitative phase, that was a probability sampling method. Data collection tools in the qualitative phase of this study were documents and resources and, in the quantitative phase, the tools were questionnaires.

- Finding: According to the findings in the qualitative phase, the study on the Iranian-Islamic happiness was done about three pervasive themes: inner happiness (vision oriented to happiness, character oriented to happiness and dynamism oriented to happiness), life oriented to happiness (happy life-world, spiritual and material well-being) and actions oriented to happiness (ritual, emotional, and social).

- Conclusion: The findings of the quantitative phase of this study indicate that the role of Iranian-Islamic happiness components in the realization of a happy school has been estimated above the average according to the statistical population of this study, and the Iranian-Islamic model for a happy school has a goodness of fit test.

Keywords: happiness, an Iranian-Islamic model, a happy school, elementary education system.

Citation: Bahramian,S., \& Nadi,M., \& Karimi,F. (2020). Providing an Iranian-Islamic Model for a Happy School in the Elementary Education System in Iran. Applied Issues in Islamic Education, 5(3): 33-60.

Received: $2020 / 06 / 18$

Accepted: $2020 / 11 / 30$

1. A Ph.D. Student in Educational Management, the Faculty of Educational Sciences and Psychology, Islamic Azad University, Isfahan Branch (Khorasgan), Isfahan, Iran.

E-mail: somayyeh_bahramian@yahoo.com. (iD 0000-0002-9940-4632

2. Corresponding Author: Associate Professor in Educational Management, the Faculty of Educational Sciences and Psychology, Islamic Azad University, Isfahan Branch (Khorasgan), Isfahan, Iran.

E-mail: Nadi2248@yahoo.com. (iD) 0000-0002-1578-0893

3. Associate Professor in Educational Management, Faculty of Educational Sciences and Psychology, Islamic Azad University, Isfahan Branch (Khorasgan), Isfahan, Iran.

E-mail: Faribakarimi2005@yahoo.com. (iD 0000-0002-8594-3790

(C) The Authors. 



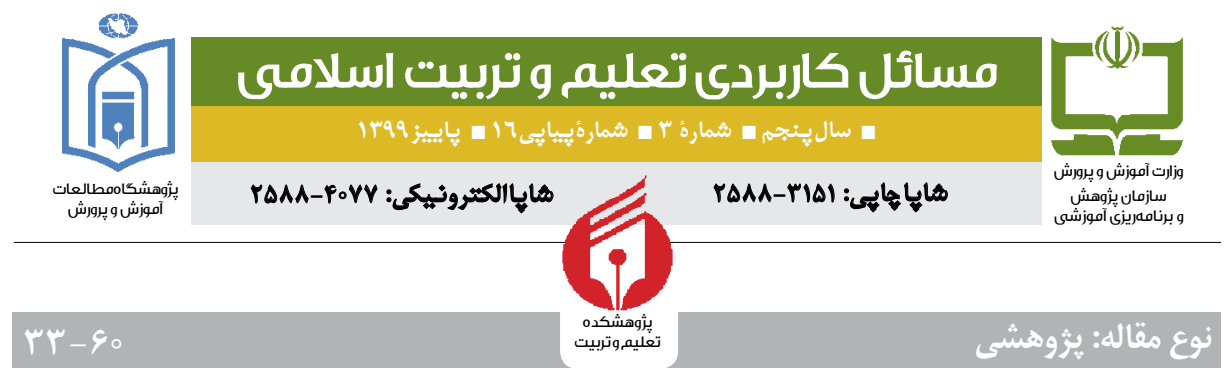

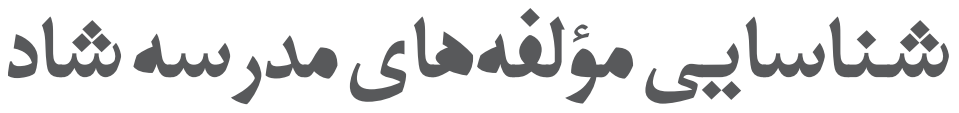 در نظام آموزث ابتندايبى ايبران

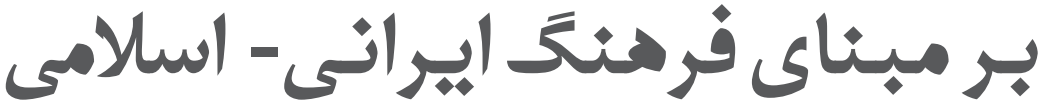

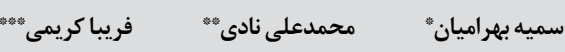
ه هدف: بروهش حاضر با هدف شناسايى مؤلفههاى مدرسه شاد در نظام آموزش ابتدايى ايران

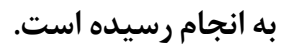

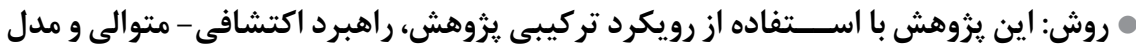

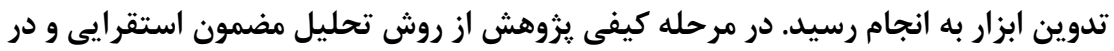

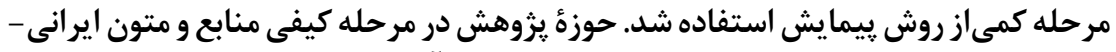

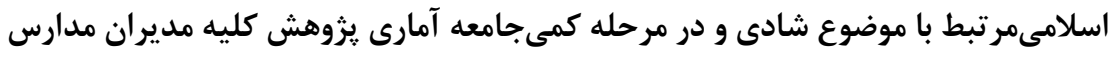

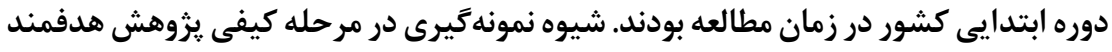

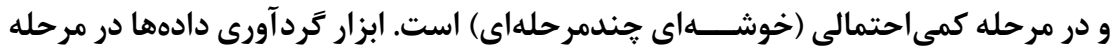

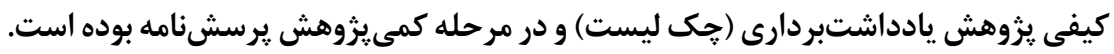

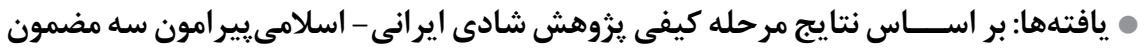

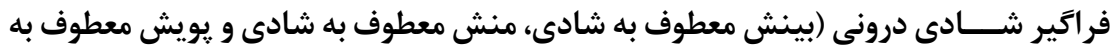

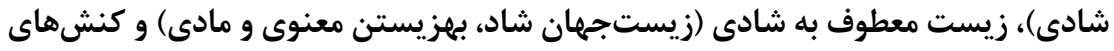

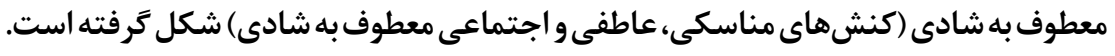

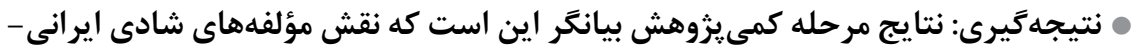

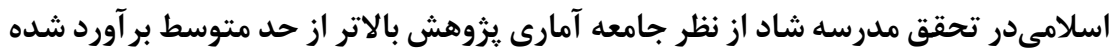

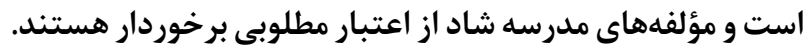

* دانشجوى دكترى مديريت آموزشى، دانشكده علوم تربيتى و روانشناسى دانشعاه آزاد اسلامى، واحد اصفهان(خوراسكان)، اصفهان، ايران. Email: somayyeh_bahramian@yahoo.com (iD) 0000-0002-9940-4632

*\%* نويسنده مسئول: دانشيار مديريت آموزشى، دانشكده علوم تربيتى و روانشناسى دانشكاه آزاد اسلامى، واحد اصفهان(خوراسكان)، اصفهان، ايران. Email: Nadi2248@yahoo.com iD 0000-0002-1578-0893

**** دانشيار مديريت آموزشى، دانشكده علوم تربيتى و روانشناسى دانشعاه آزاد اسلامى، واحد اصفهان(خوراسكان)، اصفهان، ايران. Email: Faribakarimi2005@yahoo.com (ID) 0000-0002-8594-3790 


\section{مقفمه}

تعليم و تربيت يكى از ضرورتهاى اساســى زندگى انسانها براى قرار كرفتن آنها در

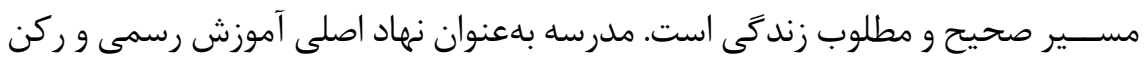

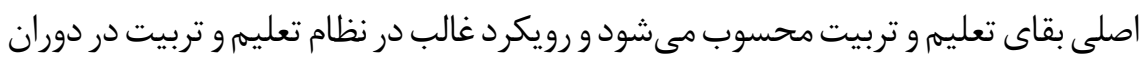

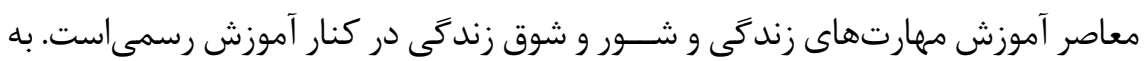

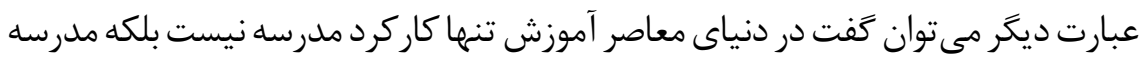

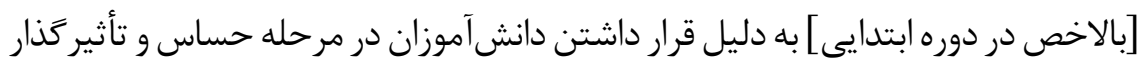

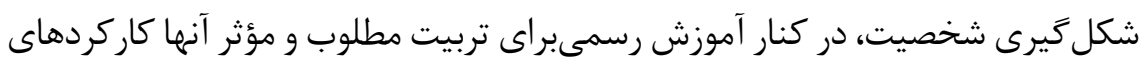

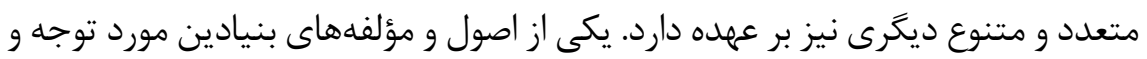

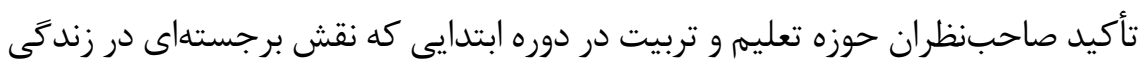

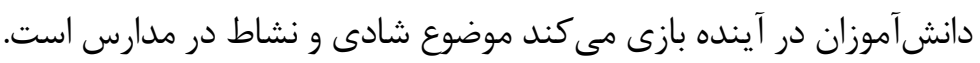

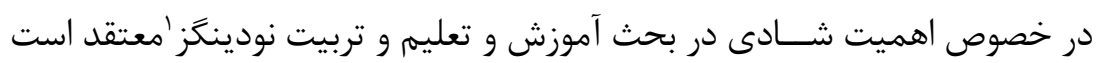

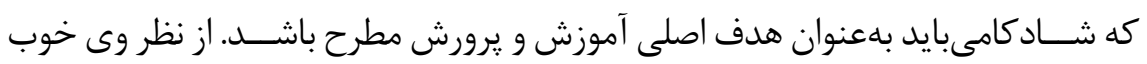

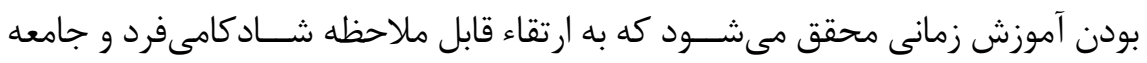

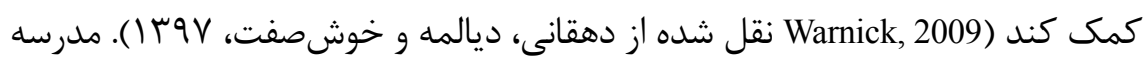

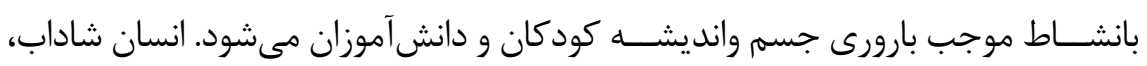

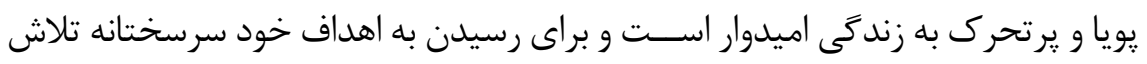

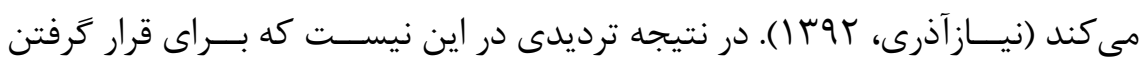

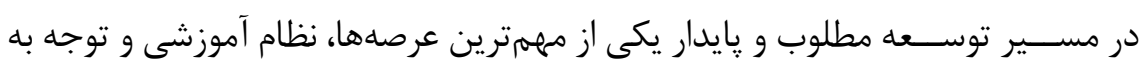

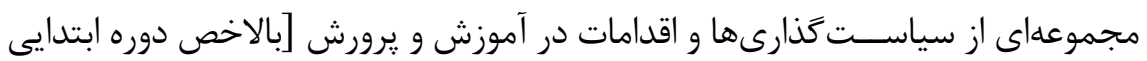

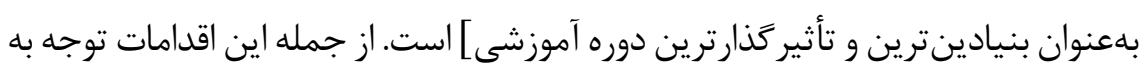

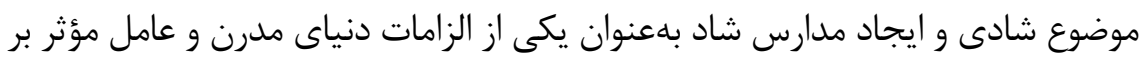

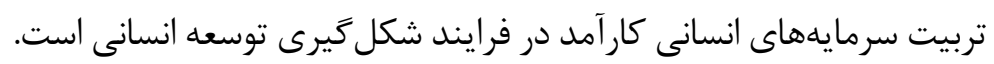

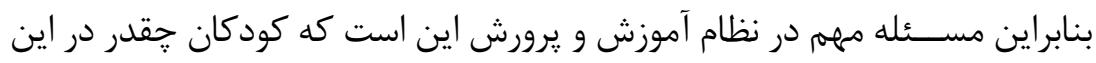

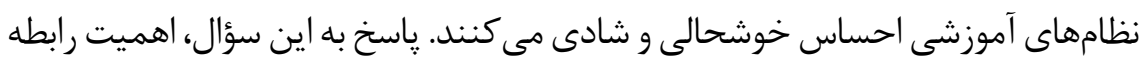

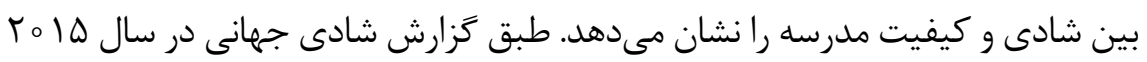


مدارسى كه شــادى در آنها در اولويت قرار داشته است، نتايج و دستاوردهاى آموزشى و اجتماعى بيشترى براى دانشآموزان داشــتهاند (Helliwell; Huang \& Wang, 2015).

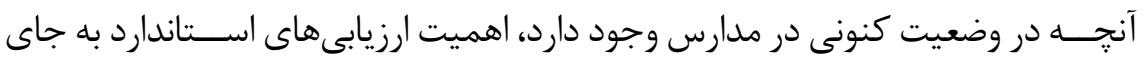
ارزيابى رشد فكرى دانشآموزان است. در واقع، هميشه ارزيابىهاى استاندارد در اولويت قرار داشــته اســت. در حالى كه براى دستيابى به يكـ مدرسه شــاد ضرورت دارد كه از تمركز روى تدريس و آزمونهاى استاندارد كذشته و در عوض كيفيت را فراتر از زمينههاى دروس آموزشــى تعريف كرد. اين امر مى تواند تنوع استعدادها، مهارتها و قابليتهاى بىنظير دانشآموزان را شــكوفا نمايد (Anderson; Coates; Gearin \& Zhao, 2015). بهعلاوه، اين امر مىتواند با تقويت شادى در دانشآموزان، از آنان نيروهايى انسانى براى كمك به جوامع صلحآميزتر، عادلانهتر، يايدارتر و در نهايت شــادتر بســازد. اين عوامل،

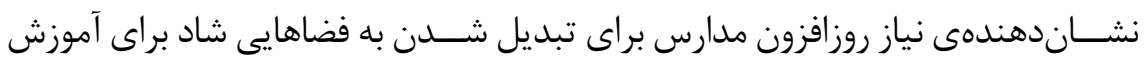
هستند (Kim, 2016). اهداف فوق در راستاى دستورالعملهاى سازمان آموزشى، علمىو فرهنگى سازمان ملل متحد (يونسكو) است كه در يادگيرى مدارس بر حوزههاى عاطفى

$$
\text { و اجتماعى با هدف ارتقاء صلح از طريق آموزش تأكيد مى كند. }
$$

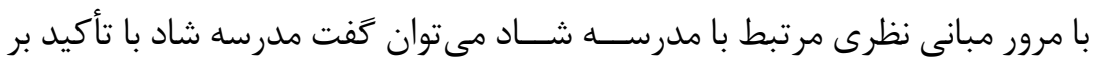
ارزشها، نقاط قوت و توانمندىهايى كه باعث افزايش شادى در يادگيرندگان مىشود، از انواع استعدادها و ايدههاى مبتكرانه استقبال مى كند و از نظامهاى آموزشى مى خواهد تا در معيارهاى ســـنـى خـــود تجديدنظر كنـند. در واقع، آنجهه در مدارس شــاد مورد تأكيد قرار مى گيرد فرمهايى از نوآورى و ايدههاى مبتكرانه براى توسعه نظام يادگيرى دانش آموزان اســت. اين مســــله در نهايت مى تواند وارد فضاى اجتماعى گســــردهتر شده و توســعه اجتماعى گايدار را به دنبال داشته باشد (Sherb, 2013; Suldo, 2016).

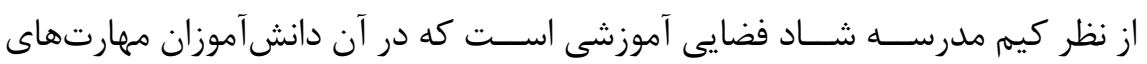

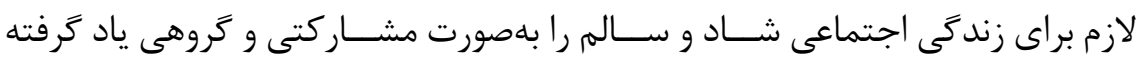
و بــا فراتيرى مـــداراى اجتماعى، خود را مهياى حضــور در عرصه اجتماعى مى كنـند

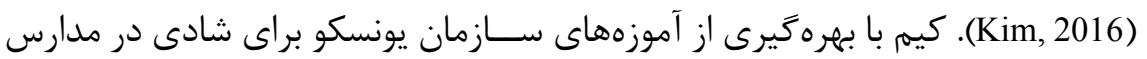
و نظام آموزشـــى، مدرسه شــاد را نظامى قلمداد مى كند كه از سه بخش اصلى تشكيل شده است: يادگيرى ((بودن)، روانشناسى مثبت گرا و يادگيرى با هم زندگى كردن. در 
يادكيرى ("بودن) بر اين مســـله تأكيد مىشود كه هدف در مدرسه شاد و فرآيندهاى آموزشى آن بايد اين موضوع باشد كه دانشآموزان مهارتهاى لازم براى زندكى شاد و سالم در آينده را تمرين كرده و ياد بخيرند. در واقع، (بودن)" در اينجا به منزله شكل دهى به نوعى وجود انسانى، سالم، شاد و خلاق در مدرسه است كه در اجتماع گستردهتر نيز بتواند زندگـىى كند. (يادگيرى زندگى كردن با هم)" اين موضوع را مدنظر قرار مىدهد كه در مدرســـه شاد بايد همه مســائل از جمله ياد كيرى بهصورت زروهى و مشاركتى صورت بخيرد تا دانش آموزان همزيســتى با يكديخر و مـــداراى اجتماعى را ياد بخَيرند (Kim, 2016). مدارســى كه شادى در آنها در اولويت قرار دارد، نتايج و دستاوردهاى آموزشــى و اجتماعى بيشترى براى دانشآموزان داشــتهاند (Helliwell et al, 2015). اين در حالى است كه نتايج برخى از يروهشها در ايران مدارس را براى دانش آموزان

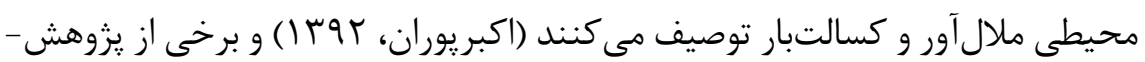
ها نيز از شــيوع افســــدى در مدارس خبر مى دهند (محمودنيا، رستخاريور و جو كار، هوس (1). همجنين مفهوم شادى از ينهانترين و مبهلمترين كلمات به كار رفته در نهاد

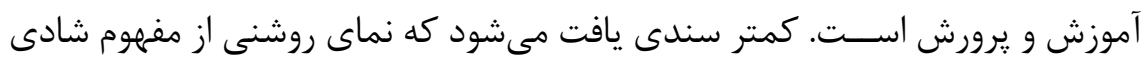
و جايـــاه آن ارائه دهد. به عبارت ديخر زمانى كـــه در نهاد آموزش و يرورش به ايجاد شــادى و نشاط در مدارس اشاره مىشود، معناى واضح و مشتركى بين توليدكنـدكان اين ييام و مخاطبانشــان وجود ندارد (هاشــمى، رضايى و اكبريوران، هوس ( ). بنابراين مى تـــوان مى كفت اين موضوع دلالت بر ايــن دارد كه در نظام آموزش و يرورش ايران برنامه مشـــص و مدونى براى شادى و ايجاد مدارس شاد وجود ندارد. البته قابل ذكر

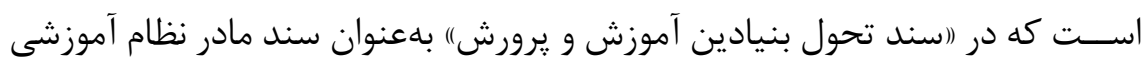
(ايجاد شادى و نشاط در مدارس") و (تربيت انسانهاى بانشاط)) از اهداف نظام آموزشى معرفى شــده است و در ساليان اخير شادى و مدارس شاد بهعنوان يكى از دغدغههاى اصلى نظام آموزشــى مطرح و مورد توجه قرار گرفته است. به عبارت ديخر سند تحول بنيادين در ززاره شــماره ده بيانيه ارزشها، نشاط را بهعنوان يكى از ززارههاى ارزشى نظام تعليم و تربيت معرفى مى كند. همجنين در فصل رينجم اين ســـند، تربيت انسان ســالم و بانشــاط بهعنوان يكى از اهداف كلان تعليم و تربيت مطرح شده است. با اين حال هنوز الكوى مشخص و مدونى در خصوص مدارس شاد در نظام آموزش و يرورش 
ايران بر مبناى فرهنَ غالب در جامعه ايران [فرهنَ ايرانى - اســلامى] ساماندهى و صورتبندى نشده است. مرورى بر يزوهشهاى انجام شده در ايران در رابطه با مدرسه شاد نشان دهنده اين

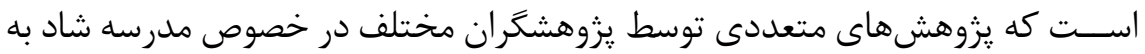

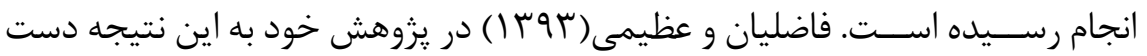

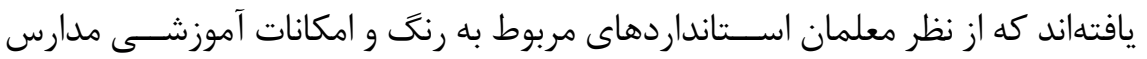

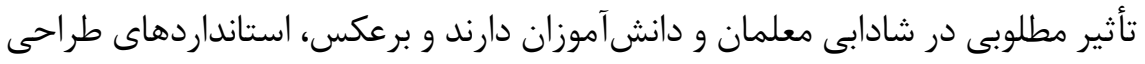

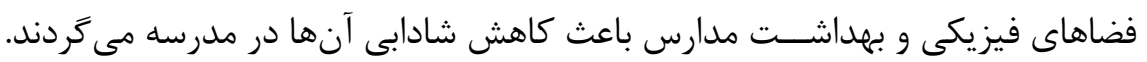

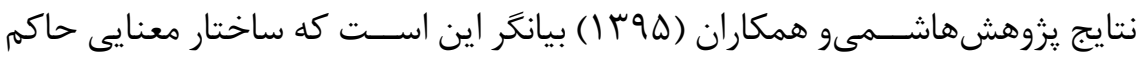

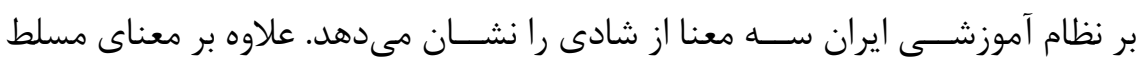

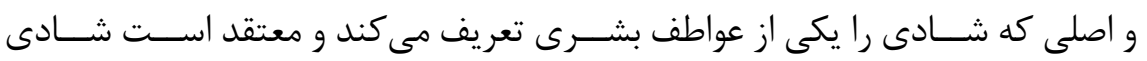

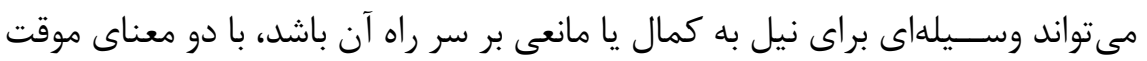

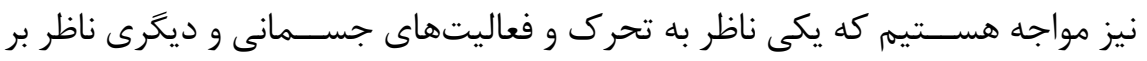

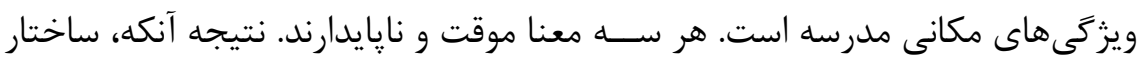

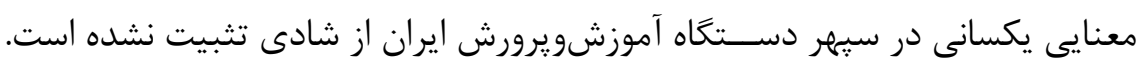

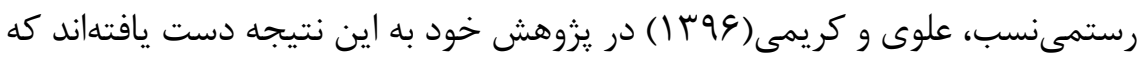

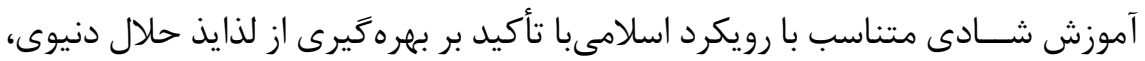

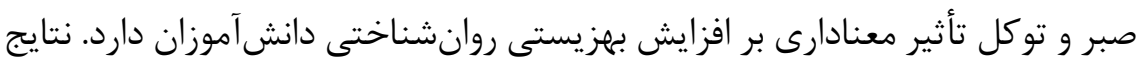

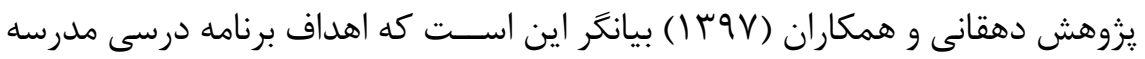

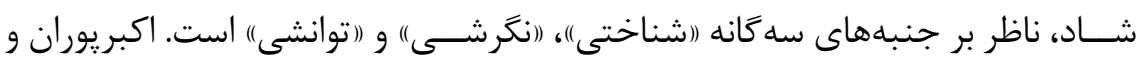

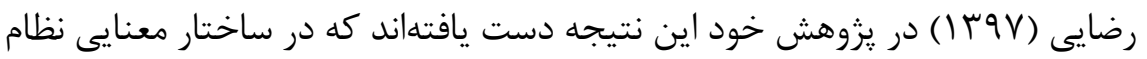

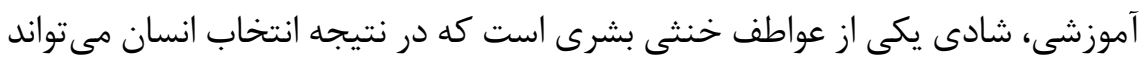

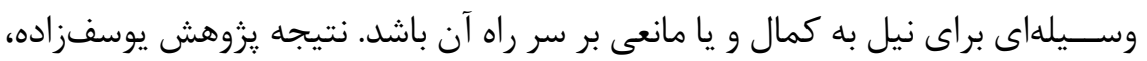

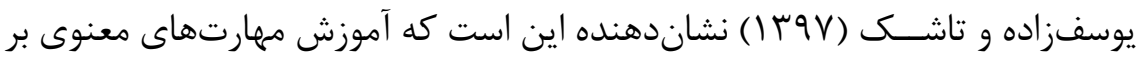
افزايش شاد كامى دانشآموزان مؤثر است.

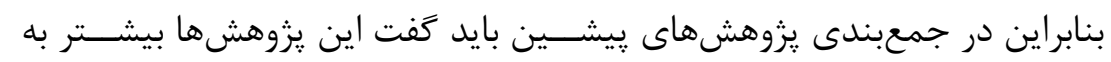

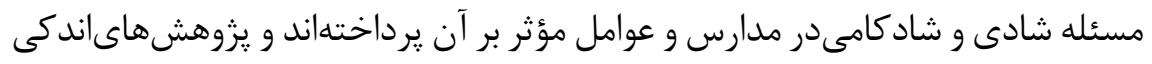


در زمينه شناســايى مؤلفههاى مدرسه انجام شده و تدوين الخوى مدرسه شاد صورت گرفته است. دهقانى و همكاران (Vو (I) در اين زمينه استثناء است و الخويى از مدرسه شــاد در ايران ارائه داده است. مســــلهُ قابل بحث در اين يزوهش اين است كه الكوى موردنظر وى تأكيد اصلى را بر برنامهريزى درســى كذاشــته است و ديخر ساختارهاى دخيل در اين زمينه را مورد توجه قرار نداده اســت. در مورد يزوهشهاى خارجى نيز همين مسئله تا حدودى صادق است. بيشتر مطالعات مورد بررسى، عوامل و مؤلفههاى تأثير گذار در ايجاد شادى در مدارس را مورد بررسى قرار دادهاند. الخوهاى موجود (براى مثال: Kim, 2016 عموماً بر مبناى مؤلفههاى فرهنگ غرب شكل گرفته و كارايى لازم و مؤثر را براى نظام آموزشــى ايران ندارند. دليل اصلى اين مسئله تفاوتهاى فرهنكى بين فرهنَ ايرانىـ اســلامى و فرهنَ غربى و تلقى متفاوت و تا حدودى متضاد اين فرهنَ ها از مسئله شادى است. شــادى و نشاط بهعنوان ضرورت فطرى انســان ها و يكى از الزامات اصلى زندكى در فرهنَ ايرانىـ اســلامى همواره مورد توجه بوده و زيست شاد جزء لاينفك اين فرهنَ محسوب مىشود. در ايران باستان شادى به مثابه الخوى فرهنگى غالب نيايشهاى دينى

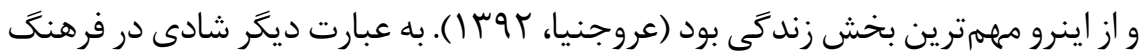
ايرانى از ديرباز مورد توجه بوده و در فرآيندى تاريخى تبديل به يكى از انكارههاى اصلى

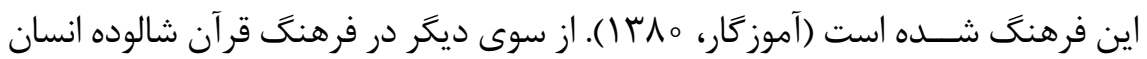
بر شــادى بنا شده و خدا انسان را موجودى شاد و بانشاط آفريده و همواره از او خواسته

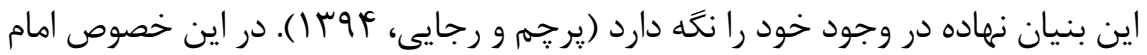
على (ع) مىفرمايند: (السرور يبســـ النفس و يثير النشاط؛ شادى باعث انبساط روح و ايجاد وجود و نشاط مىشود) (محمدى رىشهرى، (وس|). و نير در روايتى ديخر از امام

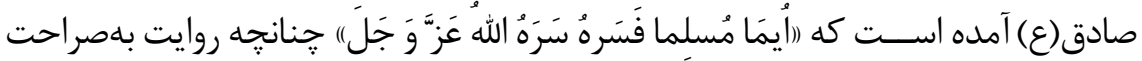
اشاره مى كند، شاد كردن مؤمنان و مسلمانان، همتراز شاد كردن خداوند قرار كرفته است (زينى ملكآباد و نيلساز، هوبا (1). علاوه بر آنجه در خصوص اهميت شــادى در فرهنَ ايرانى ــاسلامىذكر شد. باقرى

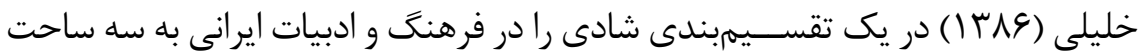
اصلى شادى انفسى (درونى)، شادى آفاقى (بيرونى) و شادى آفاقىـ انفسى تقسيمبندى 
$r r-90$

مى كند. بنا به نظر او ســاحت شادى مولوى، اساساً ســـوبز كتيو يا درونى و انفسى است.

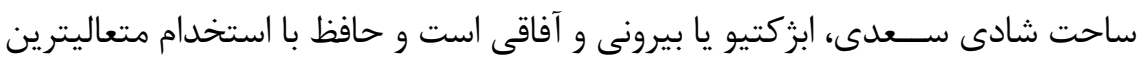

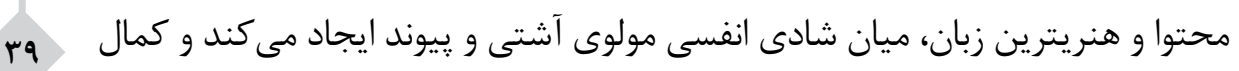

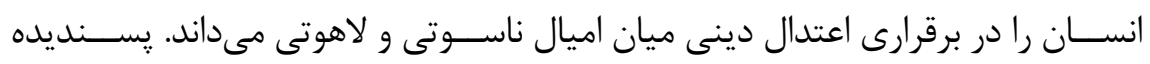

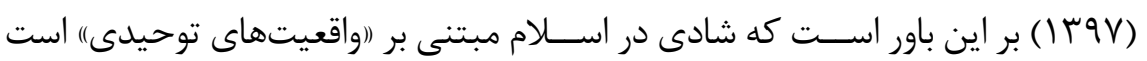

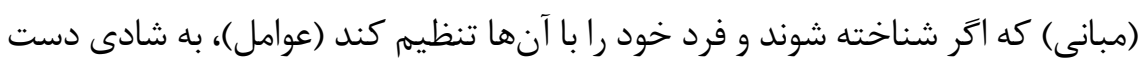

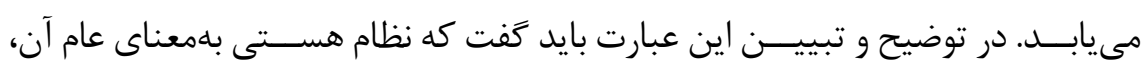

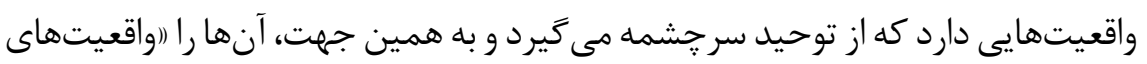

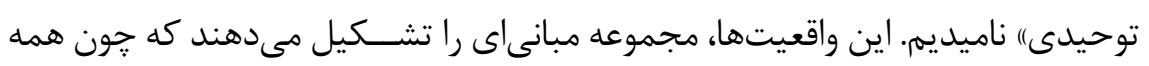

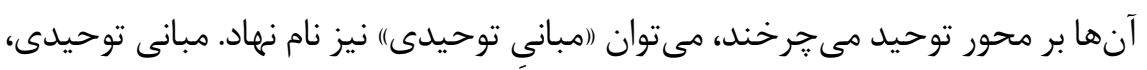

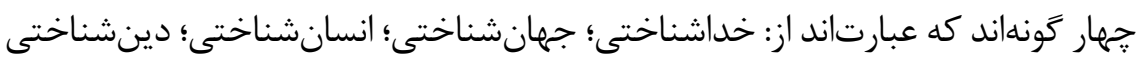

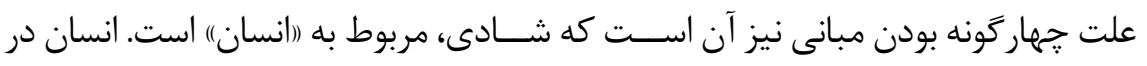

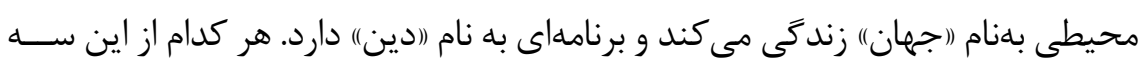

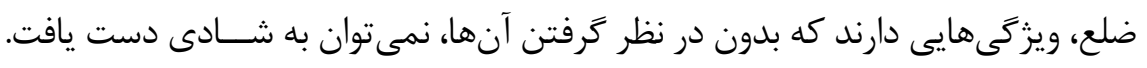

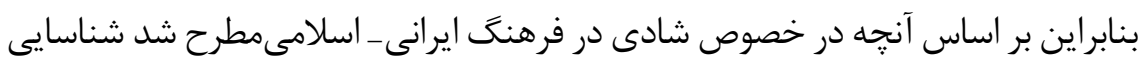

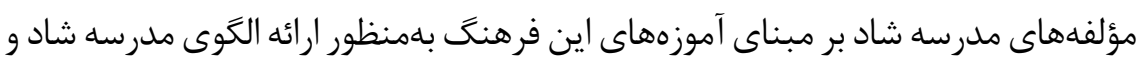

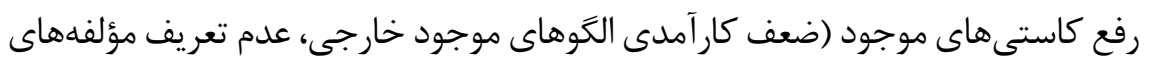

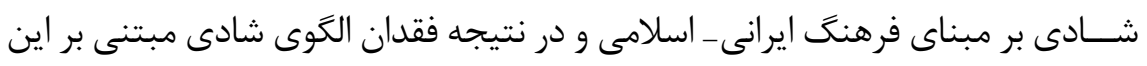

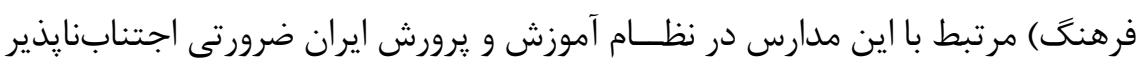

محسوب مىشود.

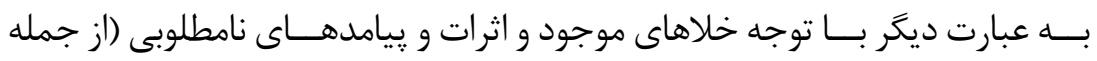

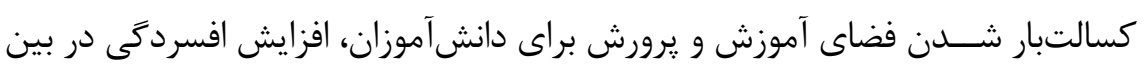

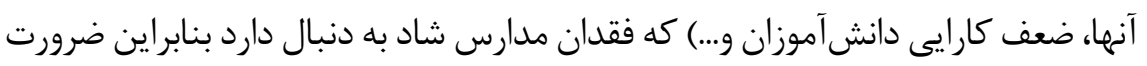

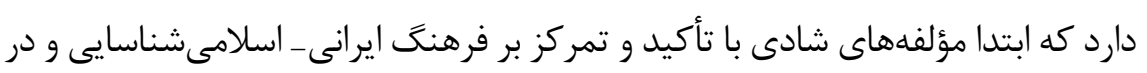

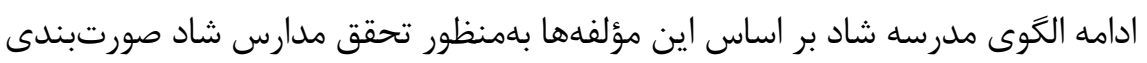

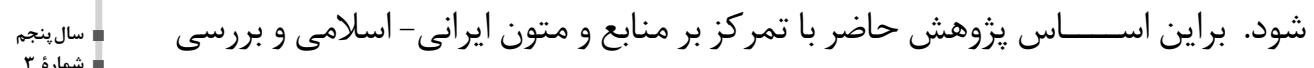

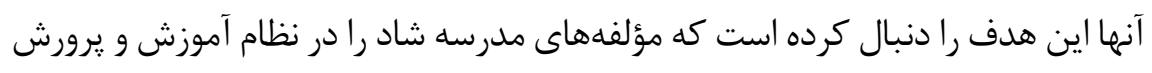


ابتدايى ايران از طريق مطالعه و واكاوى شادى در فرهنَ ايرانى - اسلامىشناسايى و ارائه كند. از اين رو سؤالى كه مطرح است اين است كه:

ا. مؤلفههاى شادى بر مبناى منابع و متون ايرانى_ اسلامى كداماند؟

r. مدرسه شاد در نظام آموزش ابتدايى ايران داراى جه ابعاد و مؤلفههايى است؟ س. آيا مؤلفههاى مدرســه شاد در نظام آموزش ابتدايى ايران از اعتبار لازم برخوردار

\section{روش رشناسى بزوهش}

روش يزوهــش حاضر از نوع تركيبى اســت. در يزوهش با روش تركيبى يزوهش

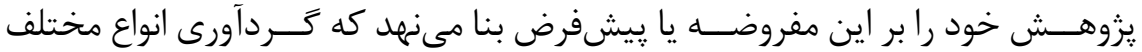
دادهها (كيفى و كمى) منجر به فهم مســئله يزوهش به بهترين وجه ميىشود (كرسول،

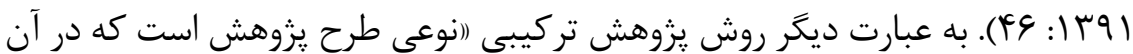
رويكردهاى كيفى و كمىدر انواع يرسـشها، روشهاى يزوهش، رويههاى جمع آورى و

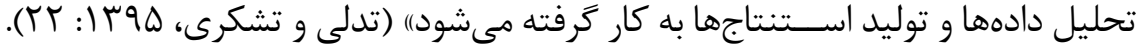
از آنجايى كه رويكرد تركيبى شـامل مجموعهاى از طرحهاى يزوهشى است كه هر كدام با توجه به مســأله و اهداف يزوهش به نحو مطلوبترى ميىتوانند ياســخكوى نيازهاى يزوهشگًران باشند. بر مبناى اهداف مدنظر طرح تركيبى مورد استفاده در يزوهش حاضر

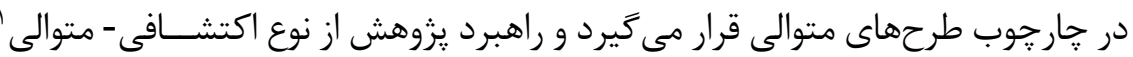
اســت. راهبرد اكتشافى - متوالى شامل گردآروى و تحليل دادههاى كيفى در مرحله اول و به دنبال آن گردآورى و تحليل دادههاى كمى در مرحله دوم كه خود بر اســاس نتايج

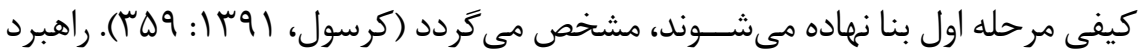
اكتشافى متوالى دو نوع متداول دارد: مدل تدوين ابزارَّو مدل تدوين طبقهبندى؟ّ. مدل مورد استفاده در يزوهش حاضر تدوين ابزار است. يزوهشخران زمانى از اين مدل استفاده مى كنند كه با توجه به يافتههاى كيفى، به تدوين و اجراى يك ابزار كمىنياز دارند. در اين يزوهش نيز با اســـفاده از مدل تدوين ابزار ابتدا بهمنظور طراحى الكوى ايرانى - اسلامى 
مدرســـه شاد و تدوين ابزار مربوط به اين الكو از رويكرد كيفى و جهت اعتبارسنجى اين الخو از رويكرد كمىيثزوهش استفاده شد.

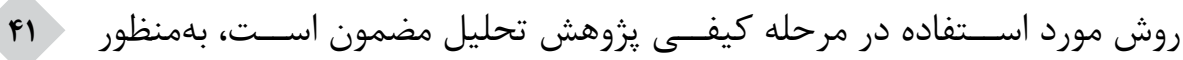

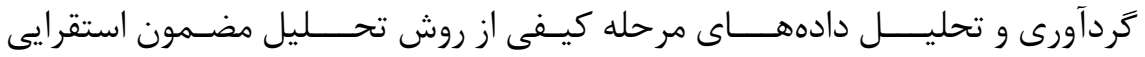

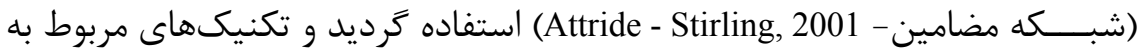

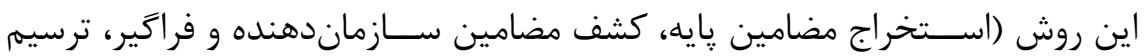
شــبكه مضامين) بهمنظور ارائه الكوى ايرانى - اسلامىمدرســـهـ شاد مدنظر و به مرحله اجرا حذاشــته شــد. با توجه به هدف يزوهش در مرحله كيفى حوزه يثروهش، يزوهش

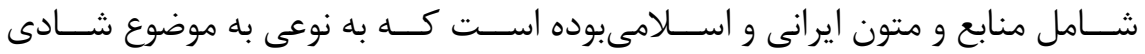

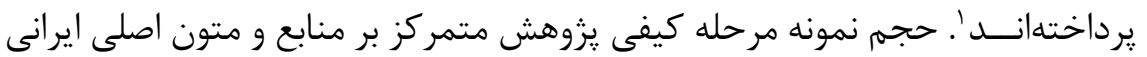
و اسلامى و محتواى اين متون بهصورت هدفمند و در راستاى تكميل فرايند استخراج و صورتبنـــى مضامين، مطالعه و مورد بررسـى و تحليل قرار زرفتند. در اين مرحله بــا توجه به ماهيت يزوهش هاى كيفى (كشــف ماهيت يكى يديده) و ززينشــى بودن راهبرد نمونه گيرى در راستاى كشف گيديده مورد مطالعه از شيوه نمونهگيرى هدفمند استفاده شد. واحد تحليل در اين منابع و متون سطر و ياراگراف بوده است. براى تحليل

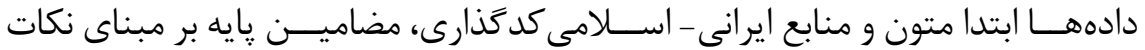
كليدى مرتبط با موضوع يزوهش استخراج و از تلخيص و تركيب مضامين يايه مضامين

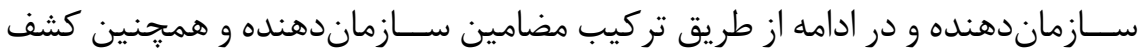
اصول حاكم بر متون مورد بررسى مضامين فراگير مرتبط با يديده شادى استخراج شد. در نهايت شــبكه مضامين مربوط هر يك از اين مضامين ترسيهم و تفسير شدهاند. براى اعتباريابى يافتههاى يزوهش در مرحله كيفى با توجه به ماهيت دادههاى مورد استفاده

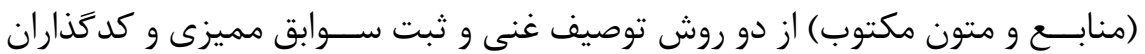
مستقل استفاده شد.

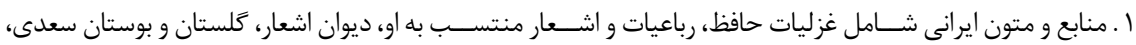

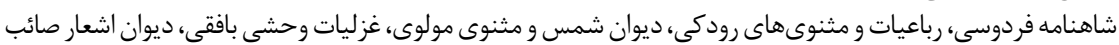

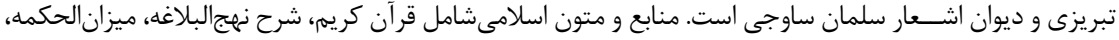

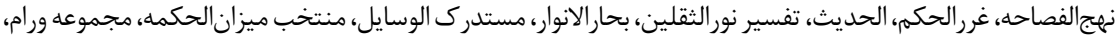

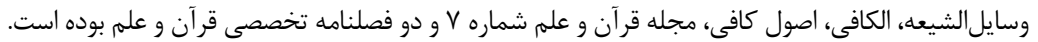


روش مرحله كمى يزوهش ييمايش است. با توجه به اهداف يزوهش مديران مدارس دوره ابتدايى آموزش و يرورش كل كشــور بهعنوان جامعه آمارى يروهش در نظر زرفته

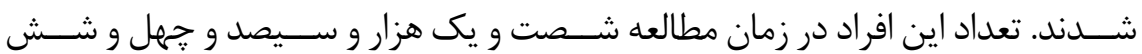

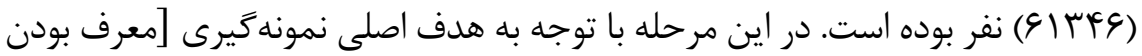
جامعه آمارى] از راهبرد نمونهگيرى احتمالى (خوشهاى جندمر حلهاى) استفاده گرديد و با مدنظر قرار دادن مفروضات مربوط به شيوه نمونه گيرى احتمالى و همجنين روشهاى تحليل آمارى در اين مرحله و شــاخصهايـى از جمله ســطح اطمينــان، توان آزمون و

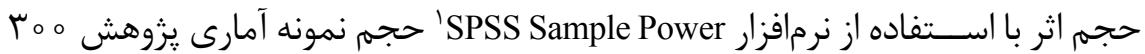
نفر برآورد گرديد. براى گردآورى دادهها از ابزار يرســشنامه محقق ساخته استفاده شد. يرســشنامه يزوهش حاضر بر مبناى مضامين فراكير شناســايى شده در مرحله كيفى يزوهش و با توجه به مضامين سازماندهنده و يايه مربوط به اين مضامين تهيه و تدوين شــــ جهت بررسى اعتبار ابزار ســـنش در اين مرحله از دو روش اعتبار محتوا (اعتبار

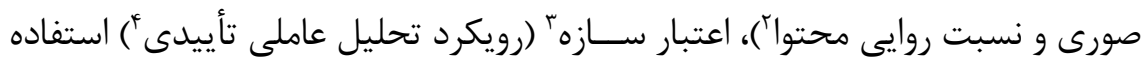

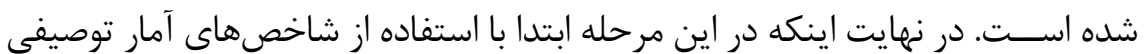
(گرايش مركزى، يراكندگى و شكل توزيع) مضامين اصلى و فرعى يزوهش توصيف و در ادامه از طريق رويكرد تحليل عاملى تأييدى و شاخصهاى مربوط به اعتبار همخرا و مميز ابتدا ابزار سنجش مضامين فراخير يزوهش و در نهايت الكوى ايرانى_ اسلامى مدرسه شاد اعتبارسنجى شد.

\section{يافتلهاى يزوهش}

بر مبنـــاى تحليل دادههاى يزوهش در مرحله كيفى مؤلفههاى شــادى در فرهنَ ايرانى - اســلامى ييرامون سه مضمون فراگير اصلى و تعدادى مضامين سازماندهنده و يايه شكل گرفته است.

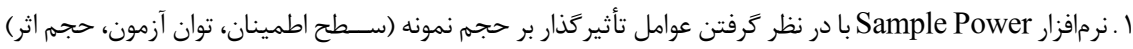

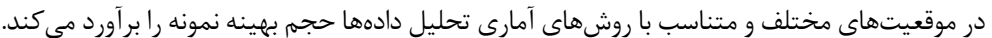

2. Content Validity Ratio (CVR)

3. Construct validity

4. Confirmatory Factor Analysis 


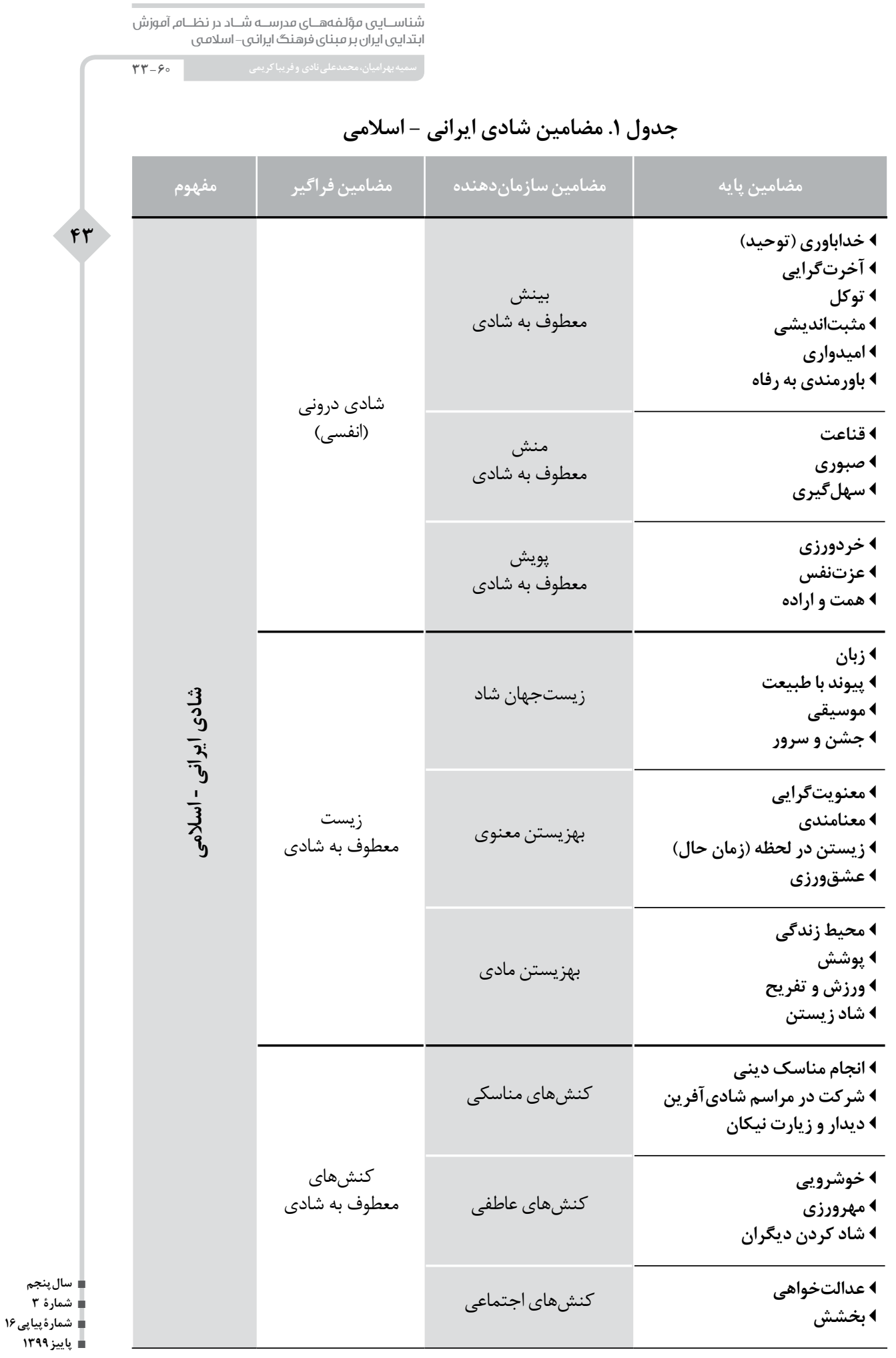


الف. شادى دوونى: شادى درونى ناظر بر جنبه درونى و به عبارت ديخر انفسى شادى

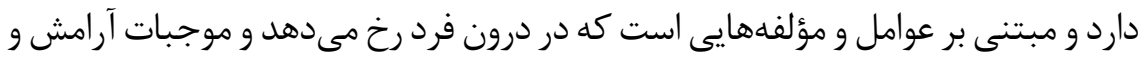

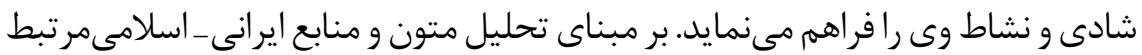
با موضوع شادى سه مضمون بينش معطوف به شادى، منش معطوف به شادى و يويش معطوف به شــادى در رابطه با مضمون فراخير شــادى درونى شناســايى و ارائه گرديد.

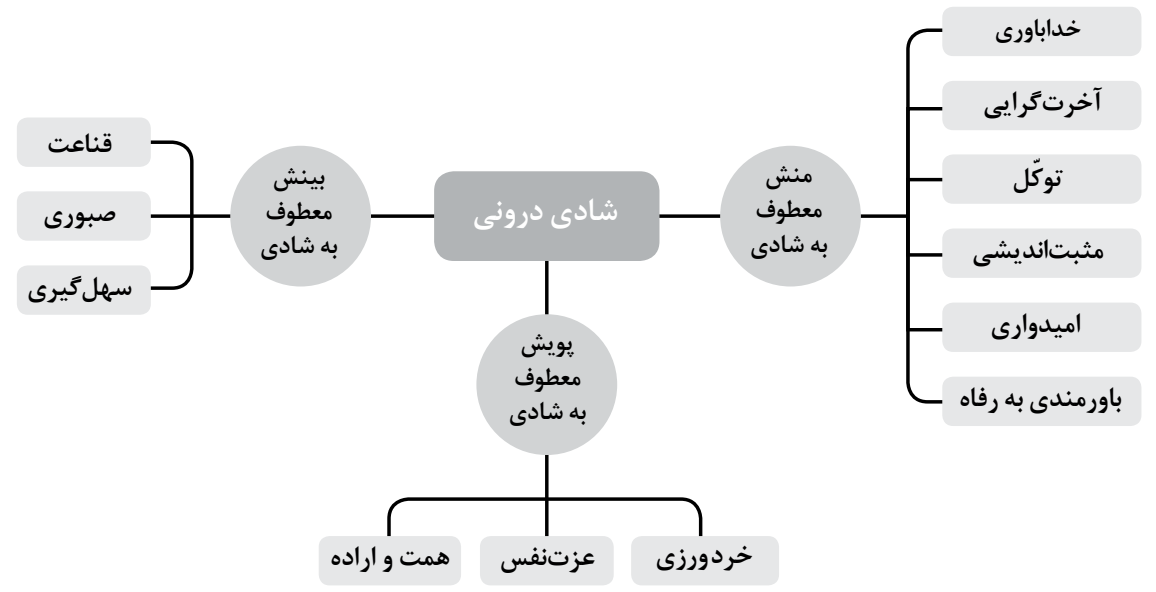

شكل 1. مضمون فراتير شادى درونى

ا. بينش معطوف به شادى: اين مضمون دلالت بر جهت

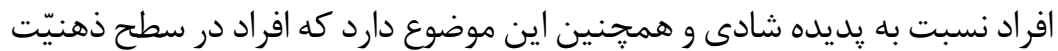

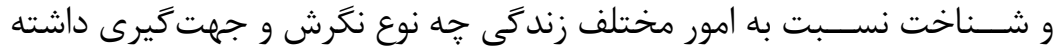

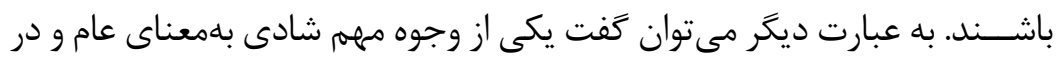

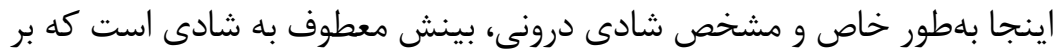

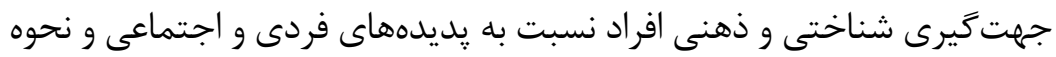

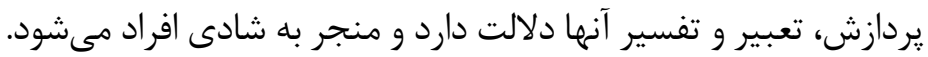
r. منش معطوف به شادى: اين مضمون كه بر مبناى تحليل متون مورد مطالعه

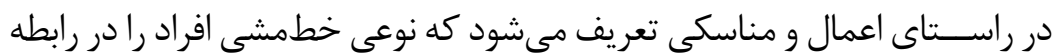

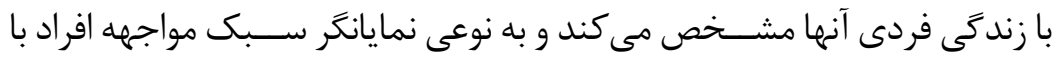
يديدههاى امور مربوط به زندگى فرد و اجتماعى است. "ا. يويش معطوف به شــــادى: بـــا توجه به تحليل متون مورد بررســى آنجه در

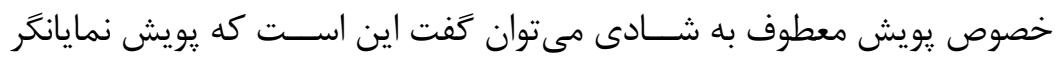


$r r-90$

فعاليتهاى درونى ييخيرانه افراد در رابطه با امور زندگى شخصى و فردى آنهاست.

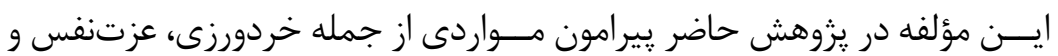

ب. زيست معطوف به شادى: از ديســـر مؤلفههاى شادى زيست معطوف به شادى است. اين مؤلفه همان گونه كه در قبل (يافتههاى كيفى) نيز مطرح شد، زيستن و زندكى كردن بر مبناى مؤلفهها و معيارهايى اســت كه منجر به شــادى و نشاط افراد مى شىود و بر مبناى تحليل متون و منابع مرتبط با فرهنگ و ادبيات ايرانىـ اسلامىدر راستاى سه مؤلفه اصلى زيستجهان شاد، بهزيستن معنوى و بهزيستن مادى تعريف شده است.
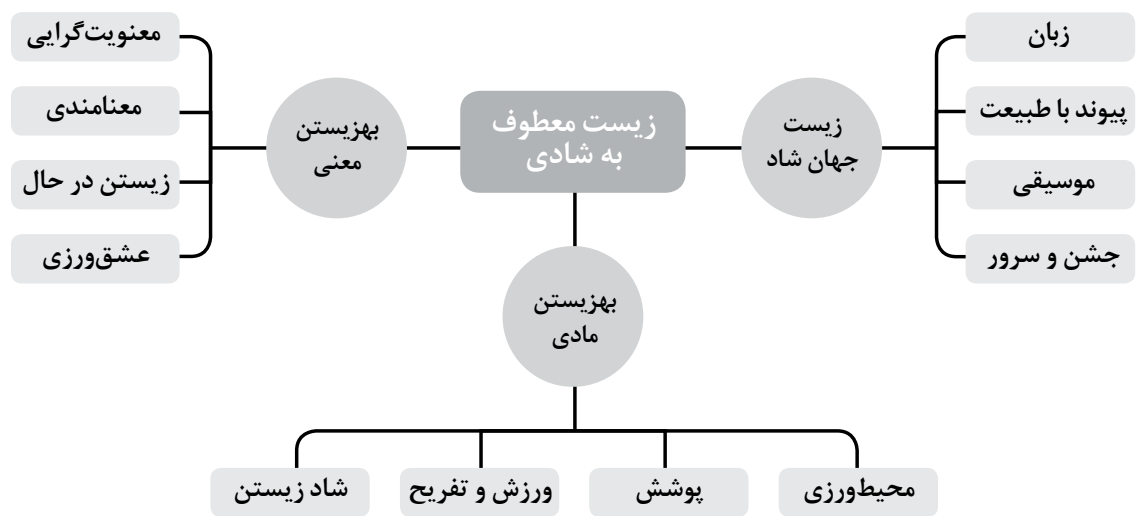

شكل r. مضمون فراتير زيست معطوف به شادى

ا. زيستجحهان شاد: مؤلفه زيستجههان شــاد ناظر بـــر تجربه روزمره يك فرد در شـــرايط محيطى و اجتماعى مشخصى است كه براى وى شادىبخش و نشاطآور

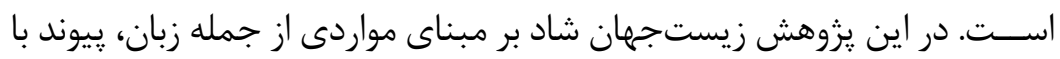
طبيعت، موســيقى و جشن و سرور تعريف و ساماندهى شده است. مىتوان كفت زيسـت جهان شاد نيز تجربه روزمره شـادى در قالب فعاليتها و تجارب شادى بخشى است كه انسانها تمايل دارند اين فعاليتها و تجارب براى آنها تكرار شود و شادى و نشاط مستمر و مداوم آنها را به همراه داشته باشد. معنوى ناظر بر لذتهايى اســت كه فرد در ارتباط با امــور غيرمادى و فرامادى 
تجربه مى كند. تمايل به معنويت، معنامندى در زندكى و زيســن در زمان حال

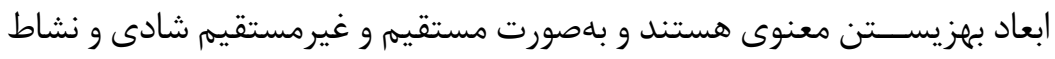

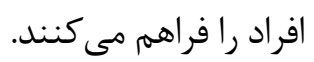

r. بهزيستن مادى: يكى ديكر مؤلفهها مرتبط با زيست معطوف به شادى بهزيستن

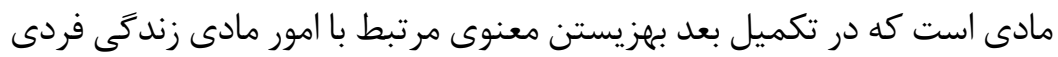

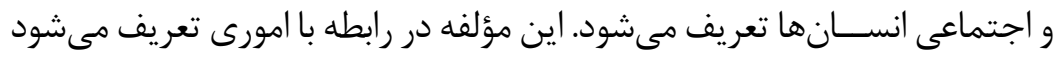

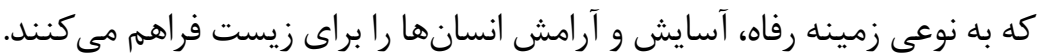

ب. كنشى هاى معطوف به شادى: در راستاى مؤلفههاى شادى درونى و زيست معطوف

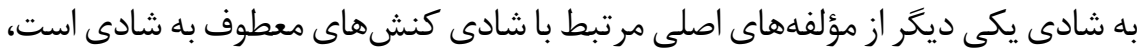

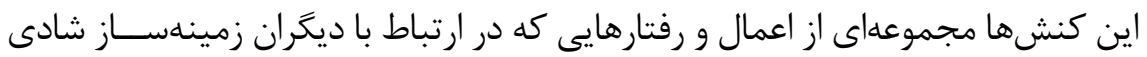
افراد هستند و به نوعى كنشهاى با محوريت شادى تعريف مى شوند و در سه ده دسته اصلى كنشهاى مناسكى، عاطفى و اجتماعى معطوف به شادى دستهبندى شدهاند.

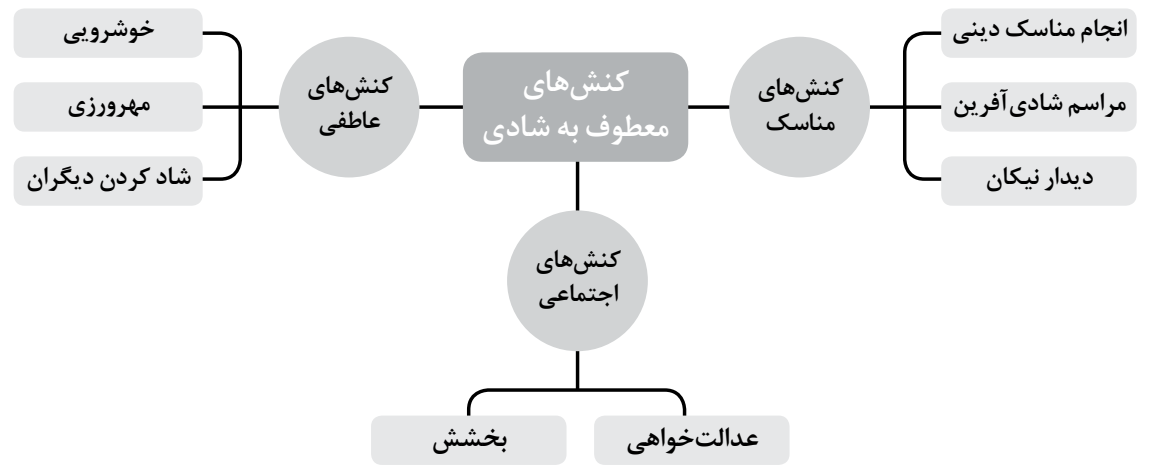

شكل r. مضمون فراتير كنشهاى معطوف به شادى

ا. كنش هاى مناســـكى معطوف به شادى: اين دســـه از كنشهاى معطوف به

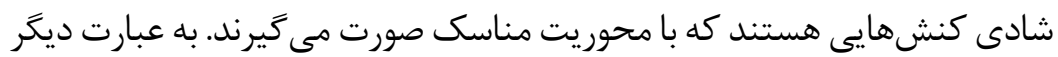

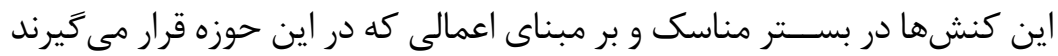

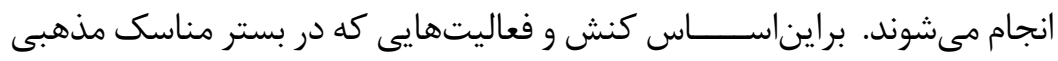

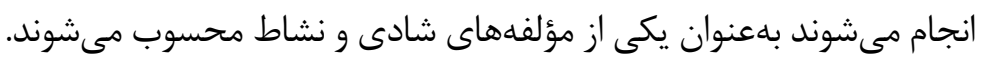


$r r-90$

r. كنش هاى عاطفى معطوف به شــــادى: كنش هــــاى عاطفى مجموعه اعمال و فعاليتهايى است كه با محوريت احساسات و عواطف شكل مى گيرند. اين كنشها اعمال و فعاليتهاى شادى آفرينى هستند كه در تعامل با ديخران با ريشه داشتن در احساســات و بر اساس عواطف تنظيمى و انجام مىشوند. در يزوهش حاضر نيز بر كنشهايى با ماهيت عواطف مثبتى از جمله خوشرويى، مهروزى و شاد كردن ديخران بهعنوان عواطف شادىبخش تأكيد شده است. r.كنش هاى اجتماعى معطوف به شــــادى: دسته ديخرى از كنش هاى معطوف به شــادى كه در يزوهش حاضر شناســايى شـــدهاند كنشهايى است كه بيشتر جنبه اجتماعى دارند و به نوعى بعد اجتماعى آنها يررنگت تر اســت. اين دســـه از كنشها بهطور خاص و مشخص در تعامل انسانها با همديخر و بر مبناى اعمال و فعاليتهاى اجتماعى تعريف مىشوند.

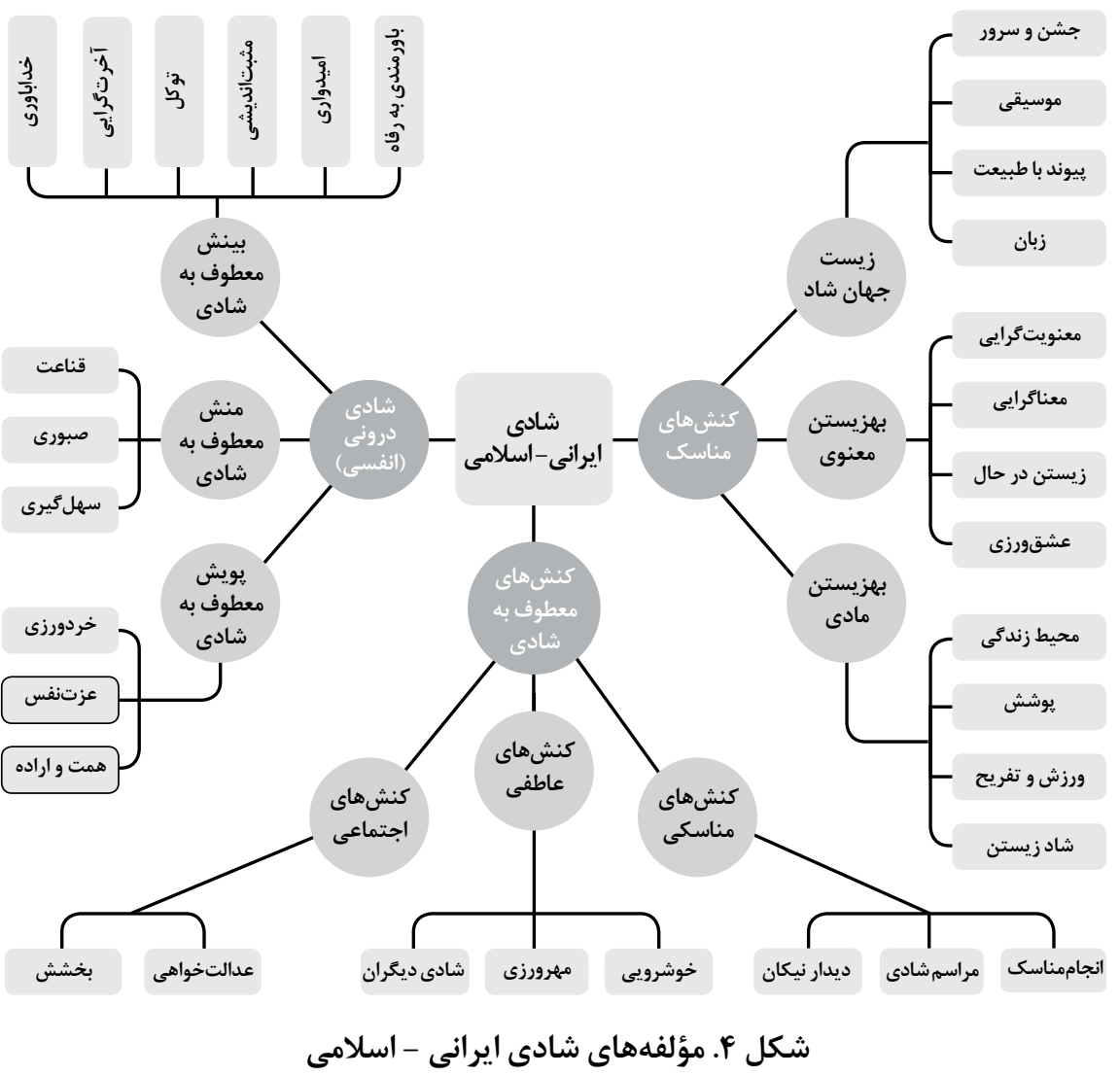


در ياسخ به اين يرسش كه مدرسه شاد بر مبناى مضامين شادى در فرهنگ و ادبيات ايرانىــ اســلامى داراى جه مؤلفههايى اســت؟؟ بايد كَفت مؤلفههاى مدرسه شاد بر مبناى مضامين شادى در فرهنَ و ادبيات ايرانى و همجنين آموزههاى اسلامى مستلزم توجه به اركان و مؤلفههاى مدرسه است. اركان و مؤلفههاى مدرسه را مىتوان در جهار دسته اصلى شــامل برنامه درسى مدارس، محيط مدارس، كاركنان (اجرايى و آموزشى) و دانشآموزان دســتهبندى كرد'، بنابر اين ارائه هر زونه سياست و برنامهاى در مدارس بايد ناظر بر همه اين مؤلفهها در يك كليت منســـهم و يكيار جه باشــــ. مؤلفههاى شادى نيز از اين قاعده مستثنى نيست، به عبارت ديخر بهمنظور تدوين مؤلفههاى مدرسه شاد بر مبناى مضامين

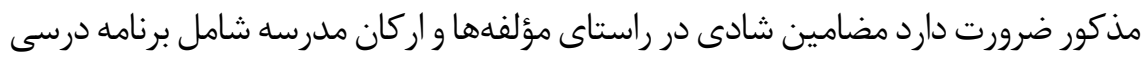
مدارس، محيط مدرسه، كاركنان مدرسه (اجرايى و آموزشى) و دانشآموزان مدنظر و مورد توجه قرار گيرد. برايناســاس بر مبناى مضامين مرتبط باشادى در ادبيات و فرهنَ ايرانىــ اسلامى مدرسه شاد مدرسهاى است كه برنامه درسى آن مبتنى بر مؤلفههاى شادى ايرانىـ

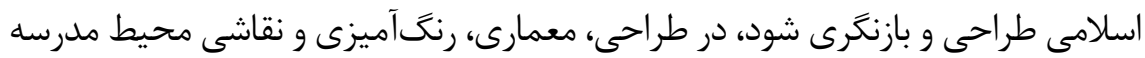
و همجنين تجهيزات آن عناصر شادى آفرين مدنظر قرار گيرد، كادر اجرايى و آموزشى اين مدارس شادى و شاد زيستن را به دانشآموزان مى آموزند و در نهايت دانشآموزان مدرسه شاد، شادى رادر اين مدرسه فراكرفته و بر مبناى مؤلفهها و عناصر آن زيست مى كنند.

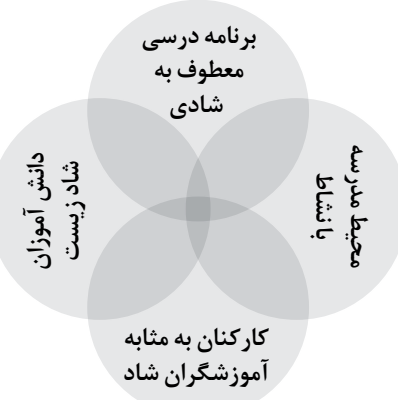

شكله. مؤلفه هاى مدرسه شاد

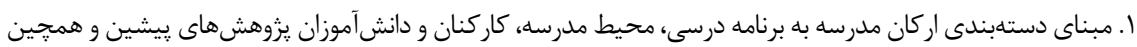

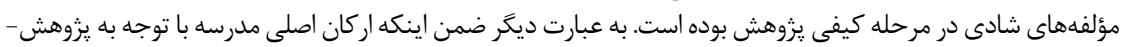

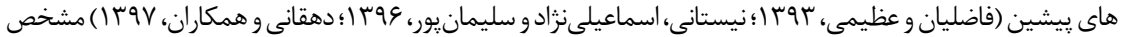

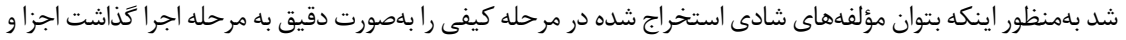

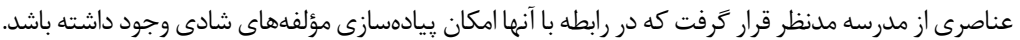




\section{يافتههاى مرحله كمى يزوهش}

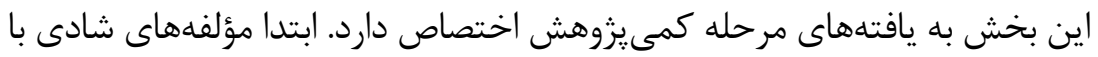

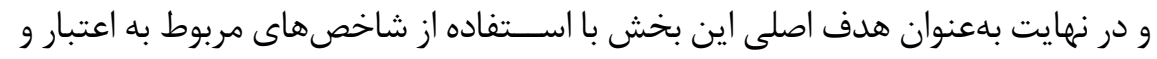

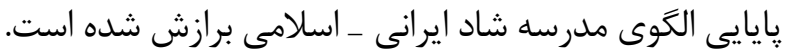

\section{جدول r. توصيف متغيرهاى اصلى بزوهش}

\begin{tabular}{|c|c|c|c|c|c|c|}
\hline \multicolumn{5}{|c|}{ شاخص } & \multirow{2}{*}{ ابعاد } & \multirow{2}{*}{ متغير } \\
\hline كشيدكى & كجى & واريانس & | انحراف معيار & ميانغين & & \\
\hline $0 / \mu Y$ & $-0 / 99$ & $\circ / T \Delta$ & $\circ / \Delta \circ$ & $F / F$ & بينش معطوف به شادى & \\
\hline 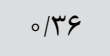 & $-1 / \circ \Delta$ & $0 / \pi$ & $\circ / \Delta \Delta$ & $\mathbb{F} / \uparrow \wedge$ & منش معطوف به شادى & شادى درونى \\
\hline$\circ / \Delta V$ & -1 & $0 / \mu Y$ &.$/ \Delta \Lambda$ & $F / T V$ & يويش معطوف به شادى & \\
\hline$\circ / \Delta \Lambda$ & $-0 / 94$ & $\circ / T \Delta$ & $\circ / \Delta \circ$ & F/fr & زيستجهان شاد & \\
\hline $1 / 1 T$ & $-1 / T F$ & $0 / T V$ & o/DT & $F / F F$ & بهزيستن معنوى & معطوف \\
\hline $1 / \varphi_{0}$ & $-1 / T F$ & $\circ / \Gamma \circ$ & $\circ / \Delta \Delta$ & $F / \Delta V$ & بهزيستن مادى & \\
\hline $0 / T_{0}$ & $-1 / 0 \Delta$ & $0 / \pi Y$ & $\circ / \Delta \Lambda$ & $f / r V$ & كنشهاى مناسكى & \\
\hline $1 / 19$ & $-1 / 14$ & $0 / T V$ & - $/ \Delta T$ & $F / \Delta \circ$ & كنش هاى عاطفى & كعنشوفاى \\
\hline$\circ / 8 \wedge$ & $-1 / T 1$ & 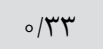 & $\circ / \Delta \Lambda$ & $F / f F$ & كنشهاى اجتماعى & \\
\hline
\end{tabular}

مقادير بر آورد شــده در جدول بالا نشــاندهنده اين اســت كه ميانخين ابعاد همه

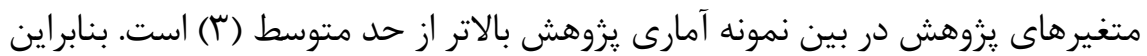

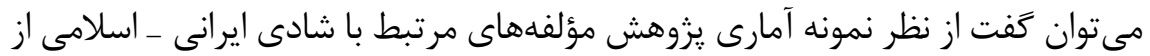
اهميت بالايى در جهت تحقق مدرسه شاد برخوردار هسند.

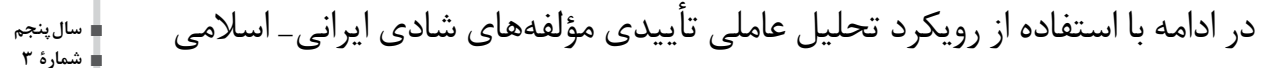


الف. شادى دورنى: مدل عاملى متغير (شادى درونى) باصورت مدل عاملى سلسهمراتبى (مرتبه دوم) تدوين گَرديد، برآوردهاى مربوط به اين مدل شــامل شاخصهاى اعتبار و קايايى و بارهاى عاملى ابعاد و مؤلفهها در شكل و جداول زير ززارش مىشود:

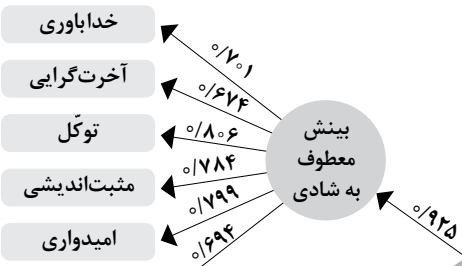

باورمندى به رفاه

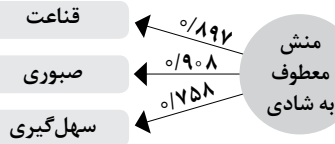

شكل 9. مدل عاملى مرتبه دوم متغير شادى درونى

جدول س. شاخصهاى ارزيابى اعتبار و يايايى ابزار سنجش متغير شادى درونى

\begin{tabular}{|c|c|c|c|c|c|c|}
\hline \multirow{2}{*}{ تربيبى } & \multirow{2}{*}{ كرونباخ } & \multicolumn{3}{|c|}{ اعتبار مميز } & اعتبار & \multirow{2}{*}{ ابعاد } \\
\hline & & خصيصه يكساوت - خصان & و فورنل & بارهاى عاملى & | متوسط واريانس & \\
\hline o/A & O/AF & \multirow{3}{*}{\multicolumn{3}{|c|}{ تأييد }} & $\circ / \Delta \Delta$ & معطوف به شادى \\
\hline ०/А9 & -/AT & & & & o/Vr & معطوف به شادى \\
\hline o/AV & o/VA & & & & $\circ / \mathrm{V}$ & معطوف به شادى \\
\hline
\end{tabular}

بر حسب مقادير جدول بالا:

ا. شاخصهاى اعتبار همخرا و مميز دلالت بر مطلوبيت اعتبار همخرا و مميز متغير

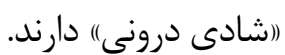




\section{$r r-90$}

ז. مقادير ضريب آلفاى كرونباخ و قابليــت اعتماد تركيبى گوياى دقتاندازهگيرى ابزار ســــش ابعاد مربوط به اين متغير و به عبارت ديخر يايا بودن ابزار سنجش

ب• زيســـ معطوف به شادى: مدل عاملى متغير (زيستجهان شاد) بهصورت مدل عاملى سلســـهراتبى (مرتبه دوم) تدوين گرديد، برآوردهاى مربوط به اين مدل شــامل شاخصهاى اعتبار و وايايى و بارهاى عاملى ابعاد و مؤلفهها در شكل و جداول زير ززارش مىشود:

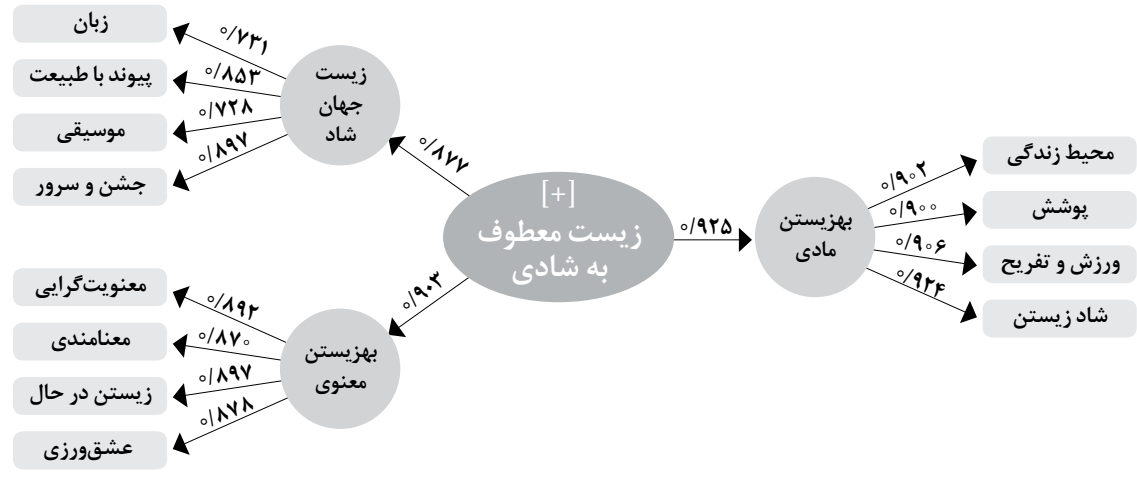
شكلVV. مدل عاملى مرتبه دوم متغير زيست معطوف به شادى جدول س. شاخصهاى ارزيابى اعتبار و يايايى ابزار سنجش متغير زيست معطوف به شادى

\begin{tabular}{|c|c|c|c|c|c|c|}
\hline \multirow{2}{*}{ تركيبى } & \multirow{2}{*}{ كرونباخ آلفاى } & \multicolumn{3}{|c|}{ اعتبار مميز } & اعتبار & \multirow{2}{*}{ ابعاد اد } \\
\hline & & خصيصه يكساوت - خصيصان & و لاركر & بارهاى عاملى متقع & استوسط واريانس شده & \\
\hline$\circ / 90$ & $\circ / 90$ & \multirow{3}{*}{\multicolumn{3}{|c|}{ تأييد }} & .190 & زيستجهان شاد \\
\hline$\circ / \sqrt{ } 9$ & $\circ / V q$ & & & & $\circ / \vee 9$ & بهزيستن معنوى \\
\hline - /AT & o/AT & & & & -/AT & بهزيستن مادى \\
\hline
\end{tabular}

بر حسب مقادير جدول بالا: الف. شاخصهاى اعتبار همخرا و مميز دلالت بر مطلوبيت سالينجه اعتبار همخرا و مميز متغير (زيســت معطوف به شــادى) دارند. ب. مقادير ضريب آلفاى 
كرونباخ و قابليت اعتماد تركيبى گوياى دقتاندازهگيرى ابزار سنجش ابعاد مربوط به اين متغير و به عبارت ديگر يايا بودن ابزار سنجش اين ابعاد است.

ب. كنشى هاى معطوف به شادى: مدل عاملى متغير (كنش هاى معطوف به شادى") بهصورت مدل عاملى سلسهمراتبى (مرتبه دوم) تدوين گرديد، برآوردهاى مربوط به اين مدل شامل شاخصهاى اعتبار و يايايى و بارهاى عاملى ابعاد و مؤلفهها در شكل و جداول

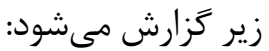

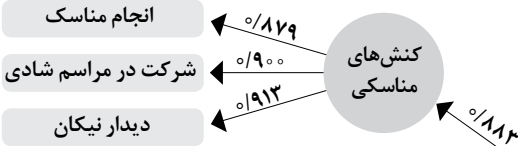
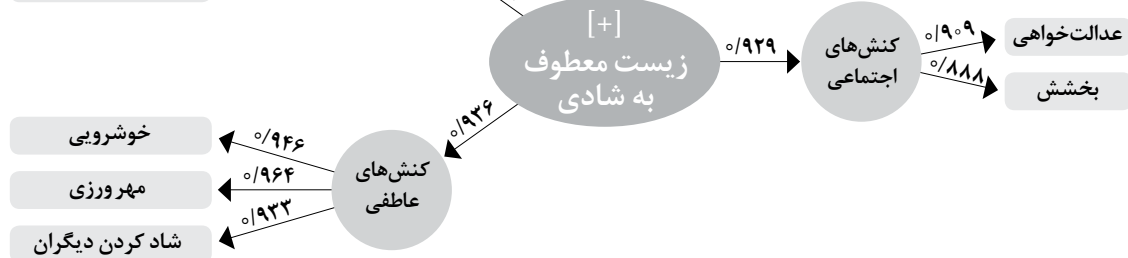

شكل ^. مدل عاملى مرتبه دوم متغير كنش هاى معطوف به شادى

جدول F. شاخصهاى ارزيابى اعتبار و يايايى ابزار سنجش متغير كنش هاى معطوف به شادى

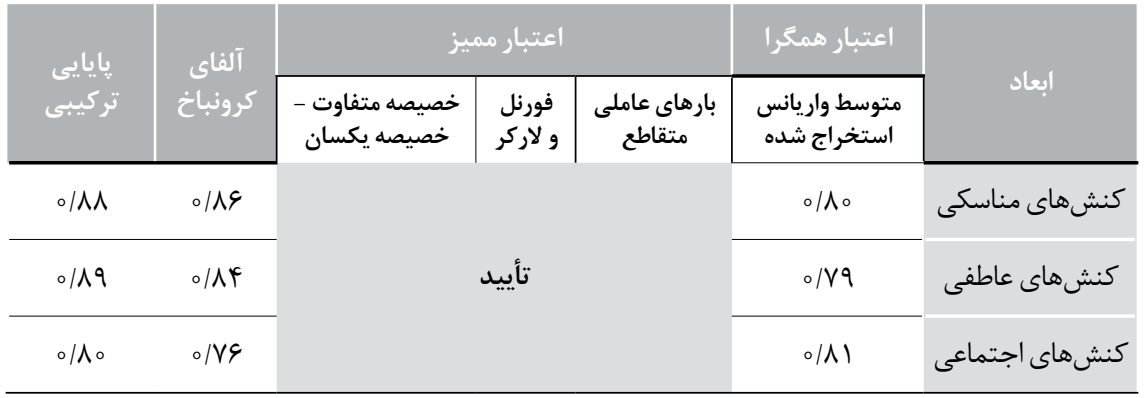

بر حسب مقادير جدول بالا:

ا. شــاخصهاى اعتبار همخًرا و مميز دلالت بر مطلوبيت اعتبار همخرا و مميز متغير (كنش هاى معطوف به شادى) دارند.

r. مقادير ضريب آلفاى كرونباخ و قابليت اعتماد تركيبى گوياى دقتاندازهزيرى ابزار سنجش ابعاد مربوط به اين متغير و به عبارت ديخر يايا بودن ابزار سنجش اين ابعاد 


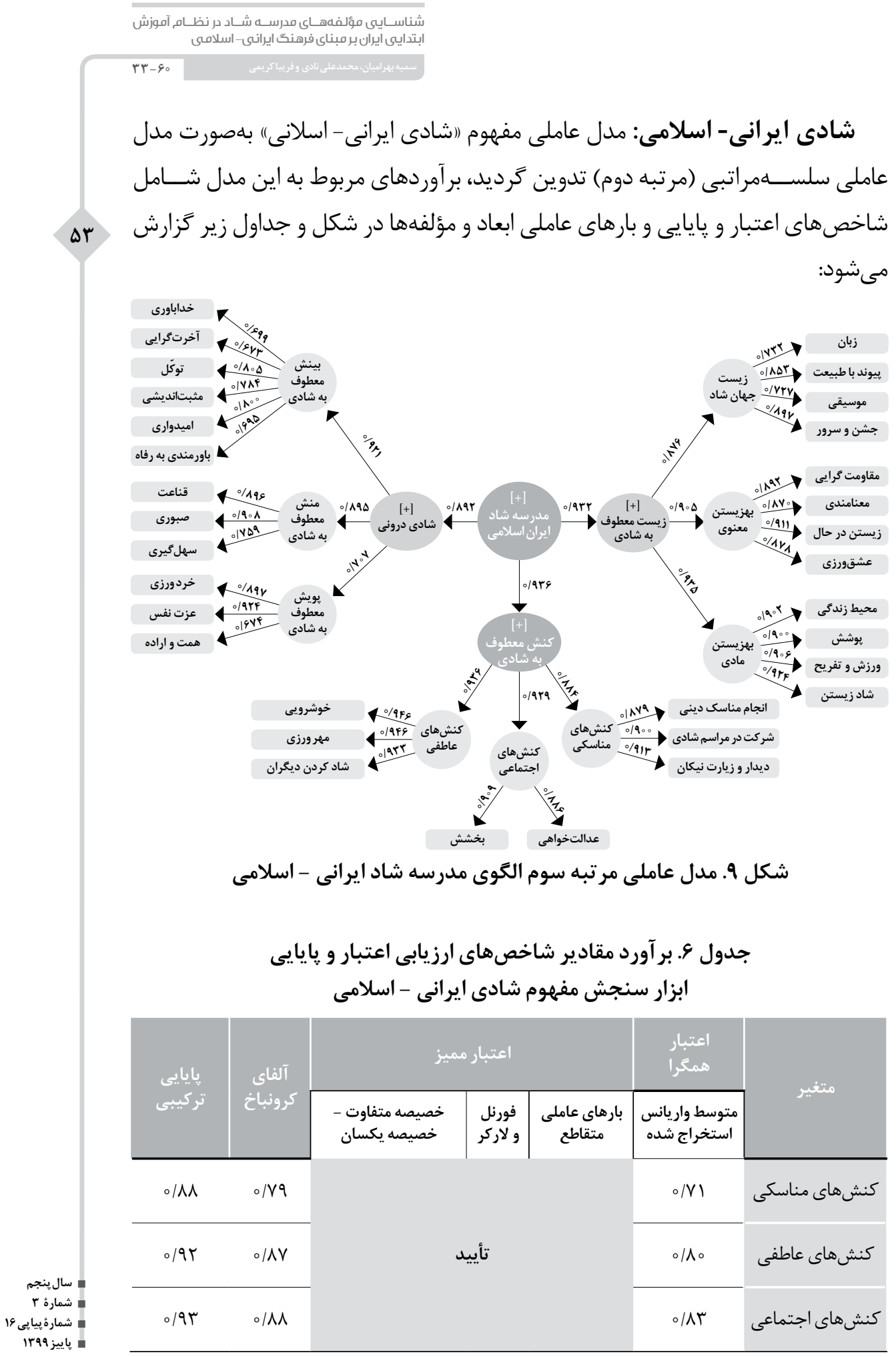


بر حسب مقادير جدول بالا:

ا. شــاخصهاى اعتبار همخًراو مميز دلالت بر مطلوبيت اعتبار همخًا و مميز مفهوم

$$
\text { (شادى ايرانى - اسلامى)" دارند. }
$$

ז. مقادير ضريب آلفاى كرونباخ و قابليت اعتماد تركيبى گوياى دقتاندازهَيرى ابزار ســــش ابعاد مربوط به اين متغير و به عبارت ديخر يايا بودن ابزار سنجش اين

\section{و نتيجهة كيرى}

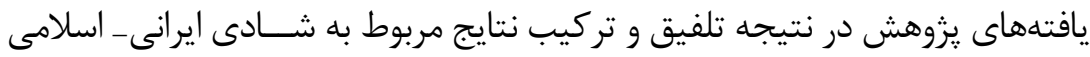
ييرامون سه مضمون فراگير و تعدادى مضامين سازمان دهنده (نه مضمون) و يايه (سى و دو مضمون) شامل شادى درونى _ انفسى (بينش معطوف به شادى، منش معطوف به شادى و يويش مطوف به شادى)، زيست معطوف به شادى (زيستجهان شاد، بهزيستن معنوى، بهزيســـن مادى) و كنشهاى معطوف به شادى (كنش هاى مناسكى، كنش هاى عاطفى، كنش هاى اجتماعى) سازماندهى گرديد. يافتههاى يزوهش در بخش كيفى همسو است با

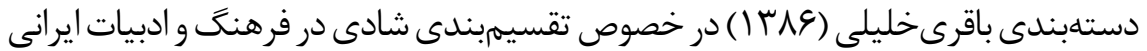
به سه ساحت اصلى شادى انفســى (درونى)، آفاقى (بيرونى) و آفاقى - انفسى و همجنين

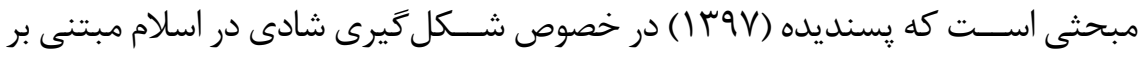
واقعيتهاى توحيدى مطرح مى كند. بنابرايــن بر مبناى يافتههاى مربوط به مرحله كيفى يثرهش مى توان كفت مؤلفههاى شادى در فرهنَ ايرانى_ اسلامىشامل سه مضمون فراخير شادى درونى، زيست معطوف به شادى و كنش هاى معطوف به شادى و همجنين مضامين سازمان دهنده و يايه مرتبط با اين مضامين است كه در ارتباط با مؤلفههاى مدرسه شامل برنامه درسى مدارس، محيط مدارس، كاركنان مدارس (كادر اجرايى و آموزشـىى) و دانشآموزان قابليت اجرا و ييادهسازى دارد. به عبارت ديگر تحقق مدرسه شاد مستلزم برنامهريزى و به كار گيرى اجزا و عناصر مضامين شادى فرهنَ ايرانى - اسلامى در رابطه با مؤلفههاى اصلى مدرسه در ساختار نظام آموزش ماته و يروش است كه در قالب جهار مؤلفه اصلى برنامه درسى معطوف به شادى، محيط مدرسه بانشــاط، كاركنان به مثابه آموزشخران شادى و دانش آموزان شادزيست نمود يريدا مى كند. 
يافتههاى كمىيزوهش بيانكر اين است كه نخست نمونه آمارى يزوهش نقش مؤلفههاى

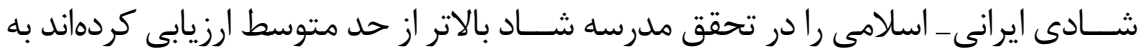

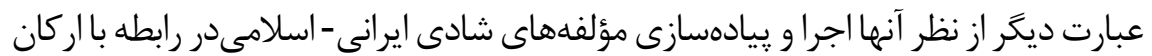

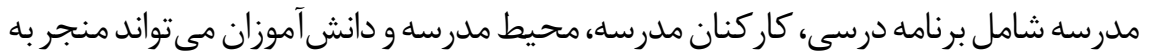

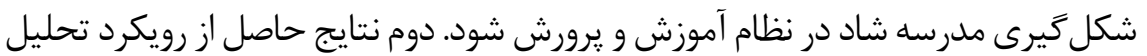

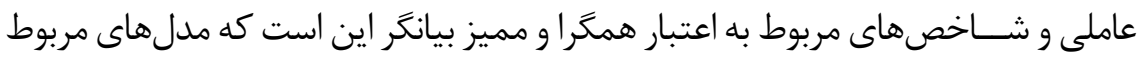

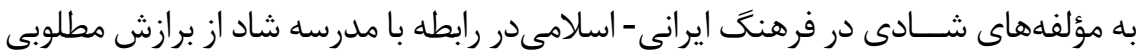

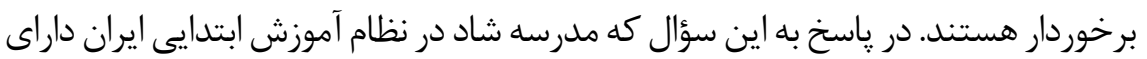

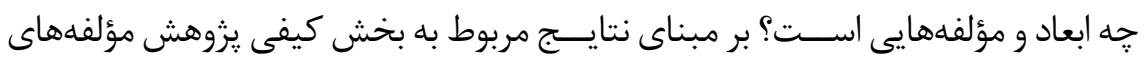

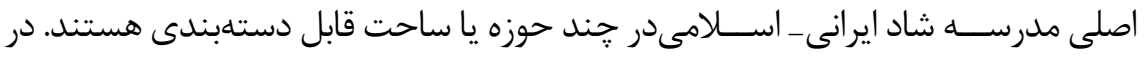

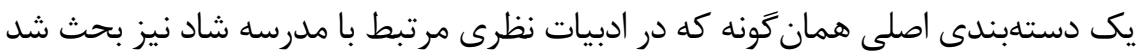

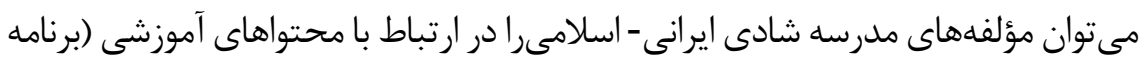

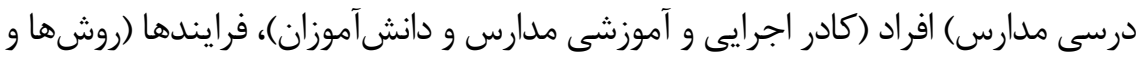

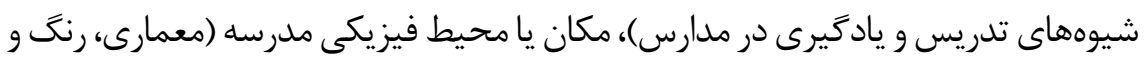

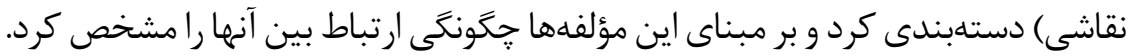

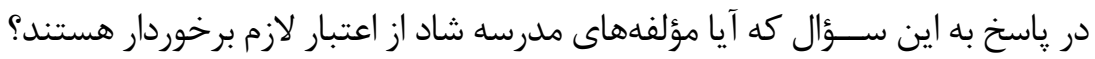

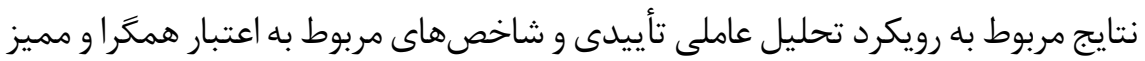

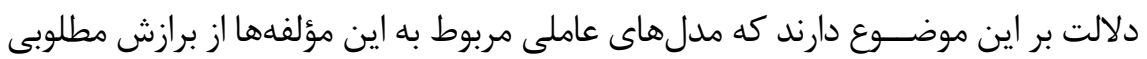

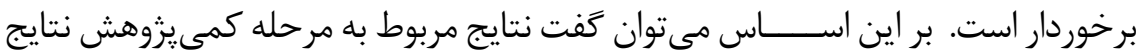

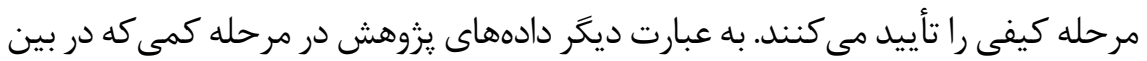

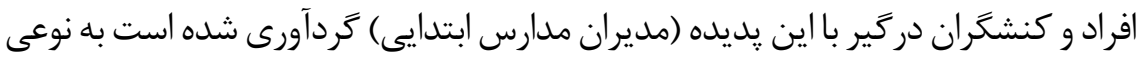

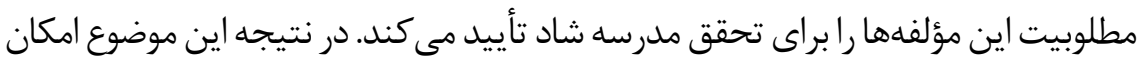

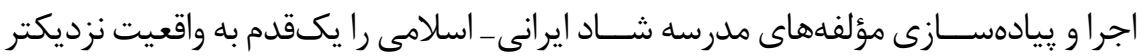

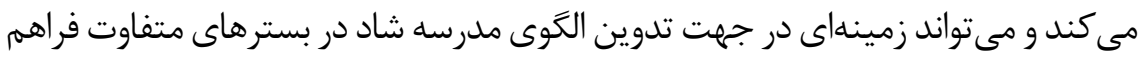

با توجه به اينكه هدف اصلى يزوهش حاضر شناسايى مؤلفههاى مدرسه شاد بر مبناى

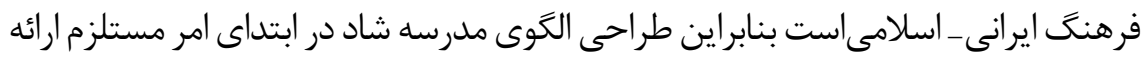


تعريف روشن و شفاف از شادى و نشاط و همجنين توجه به خاستخاه شادى و ارتباط آن با بسترهاى تاريخى و فرهنكى افرادى است كه در يك جامعه زيست مى كنند، اين قسمت از الكوى مدرسه شاد بنابر آنجه در منابع و متون ايرانى - اسلامىدر خصوص شادى ارائه گرديد تا حد زيادى از طريق شناســايـى مضامين شادى روشــن گرديده است، در ادامه بهمنظور تدوين الكوى جامع و دقيق مدرسه شاد و ييادهسازى آن در مدارس ضرورت دارد در رابطه با اركان و مؤلفههاى مدرســه (برنامه درســى مدارس، محيط مدرسه، كاركنان [اجرايى و آموزشى] و دانش آموزان) مجموعهاى از اقدامات را مدنظر و به اجرا حذاشت: با توجه به يافتههاى يثوهش در دو بخش كيفى و كمىبهمنظور طراحى و تدوين برنامه درسى معطوف به شادى بر مبناى مؤلفههاى شادى در فرهنگ ايرانى - اسلامىضرورت دارد ابتدا توافقى در بين سياست گذاران و برنامهريزان نظام آموزش و يرورش در خصوص گنجاندن اين مؤلفههاى در برنامه درســى و محتواهاى آموزشى صورت كيرد و در ادامه كارشناسان حوزه آموزش و برورش با مدنظر قرار دادن جنبهها و ابعاد شادى ايرانى_ اسلامىاين موارد را بهصورت كاملاً هدفمند و با توجه به جنبههاى شناختى، عاطفى و رفتارى مرتبط با آن در بر برو سرفصل هاى درسى دانشآموزان به شيوههاى مختلف و متنوع قرار دهند. مولفهُ مهامم ديخر مدرســـه شــاد بازطراحى محيط فيزيكى مدارس مبتنى بر عناصر و اجزاى شادى در فرهنَ ايرانى - اسلامىاست. ايجاد محيط مدرسه شاد و بانشاط مستلزم طراحى و بازطراحى محيط مدارس مبتنى بر معمارى شاد و هيجانانكيز، رنتَآميزى فضاى فيزيكى مدارس با استفاده از رنتهاى شاد و نشاطبخش، استفاده از تجهيزات و امكانات با رنگهاى متنوع و شاد، زيباسازى مدارس از طريق نقاشى و همجنين نصب تابلوهاى مربوط به طبيعت در محيط مدرســهـ و كاشــت كل و گياه در محيط مدرسه و همجين قراردادن كلدان هاى گل هاى طبيعى در فضاى راهروهاى مدارس است. از ديخر مؤلفههاى مدرسه شاد كادر اجرايى و آموزشى آموزشگر شادى در مدارس است

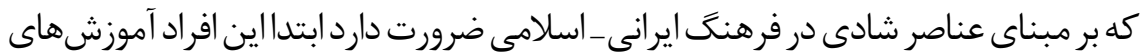
لازم را در خصوص محتواهاى آموزشى و همجنين اجراى سياستهاو برنامههاى مرتبط با مدرسه شاد فراگيرند. در ادامه توانمندى و عملكرد اين افراد در خصوص اجراى سياستها و برنامههاى مرتبط با مدرسه شاد بهصورت مستمر مورد ارزيابى قرار زرفته و مبناى داورى درباره ميزان موفقيت آنها در تحقق اين سياستها به نحو مطلوب باشد. 
در نهايت اينكه در رابطه با تحقق مههمترين مؤلفه مدرســهـ شــاد يعنى دانشى آموزان

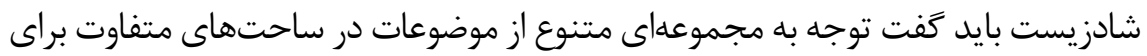

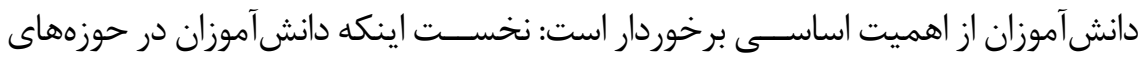

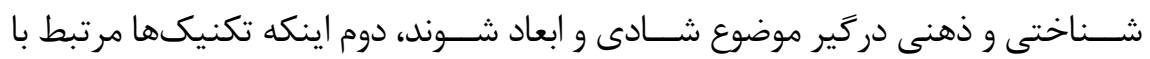

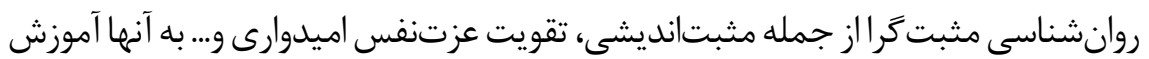

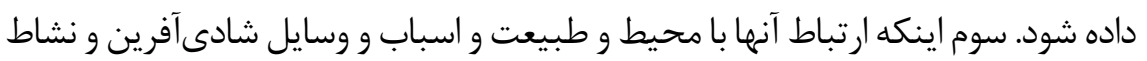

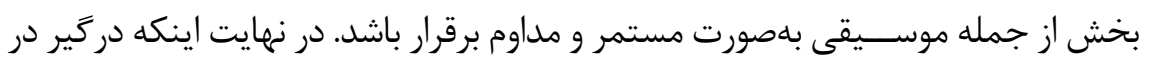

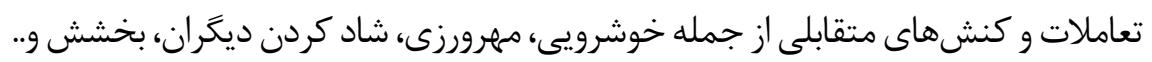
كه معطوف به شادى و نشاط است شوند. با توجه به اين موضوع كه يزوهش حاضر متمركز بر منابع و متون ايرانى - اسلامى ابعاد

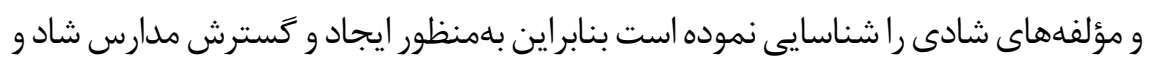

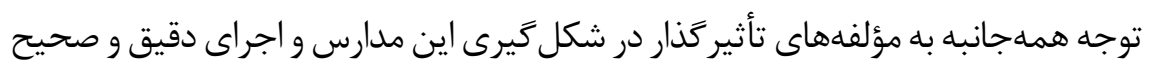

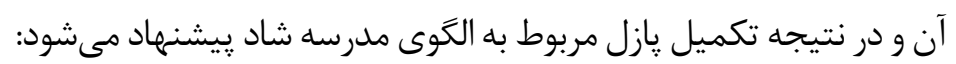

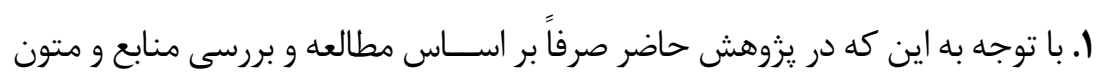

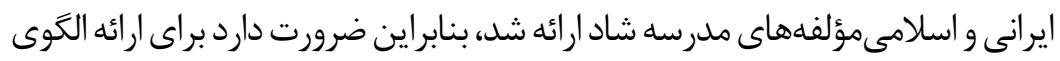

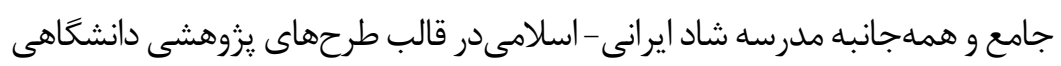

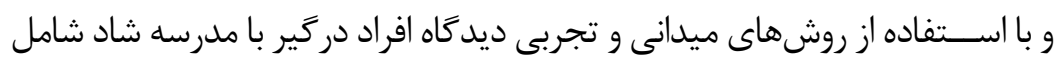

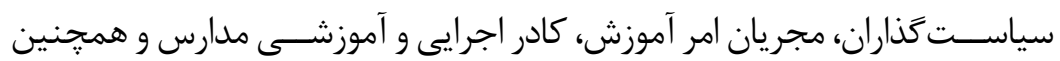

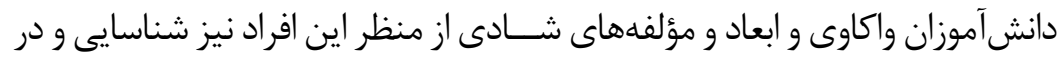

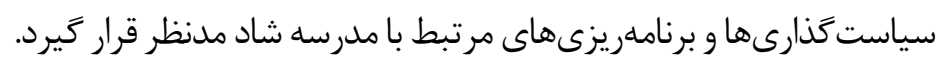

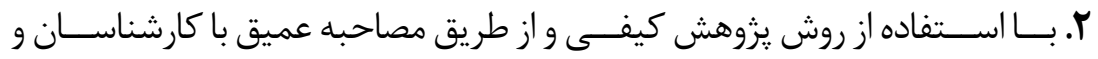

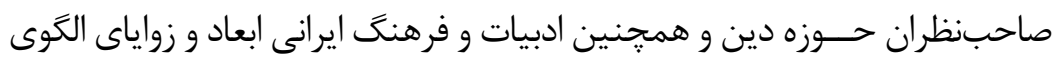

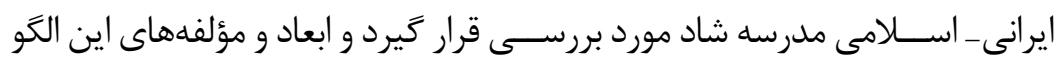

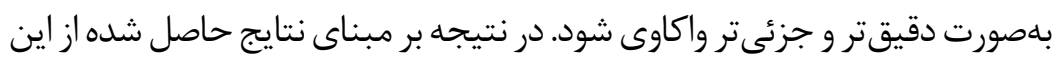

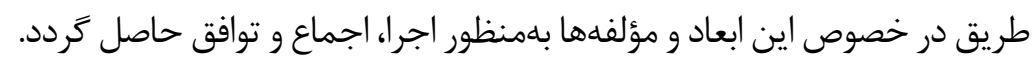

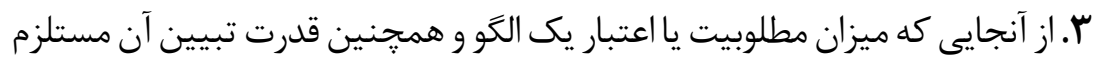

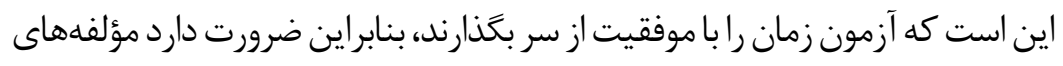


شناسايىشده در اين يثروهش بهمنظور آزمونيذيرى و در نهايت اجرا در نظام آموزش و يرورش توسط ساير يزوهشـــران اين حوزه در محيطهاى آموزشى مورد آزمون تجربى قرار گرفته تا از اين طريق در خصوص اعتبار و دقت اين مؤلفهها و همجنين تعميميذيرى آن به محيطهاى آموزشى داورى دقيقتر و جامعترى صورت گيرد.

F F. در نهايت اينكه مؤلفههاى ايرانى - اسلامىمدرسه شاد بخشى از واقعيت مدرسه شاد را يوشش مى دهد بنابراين يوشش همهُ واقعيت مدرسه شاد مستلزم واكاوى ابعاد و مؤلفههاى اين مدرسه در ساير مكاتب و رويكردهاى موجود است. از آنجايى كه هر فعاليت يثزوهشـى با محدويتهاى مواجه اســت بنابراين مهرمترين محدوديتهاى يزوهش حاضر را مىتوان اينگُونه مطرح كرد: ا. با توجه به تمركز بخش كيفى بر متون ايرانى - اســلامىمرتبط با شادى الكوى ارائه شده در خصوص مدرسه شاد از جامعيت لازم و كافى برخوردار نيست. r. از ديخر محدوديتهاى يزوهش حاضر تأكيد و تمركز بر دوره ابتدايى در نظام آموزش و يرورش ايران است و در خصوص به كارگيرى آن در ساير دورههاى آموزشى دجار محدوديت است. r. ديخر محدوديت يزوهش حاضر و الگوى ارائه شــده براى مدرسه شاد اين است كه اين الخو محدود به بخشى از واقعيت مدرسه شاد است و همه ابعاد و زواياى مدرسه شاد را در برنمى گيرد.

\section{تشكّر و قدردانى}

اين مقاله بركرفته از رساله دكترى نويسنده اول در مديريت آموزشى است. نويسندگان اين مقاله مراتب سياس و قدردانى صميمانه خود را از همكارى متخصصين وصاحب نظر ان عر صههاى آموزش، روانشناسى و ادبيات بويزه سركار خانم دكتر نركس سعيديان، سركارخانم دكتر ايلناز سجاديان و جناب آقاى دكتر عبدارضا مدرسزاده كه با نظرات ارزشمند خود زمينه انجام هر:جه بهتر اين يزوهش را فراهم آوردند، اعلام مىدارند 


\section{منابع}

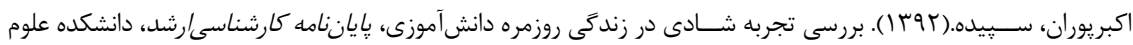

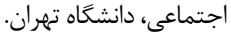

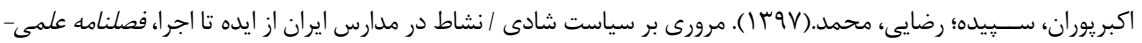
[Doi: 10.22059/ppolicy.2018.67872]

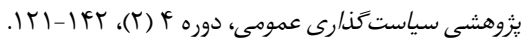

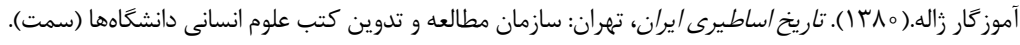

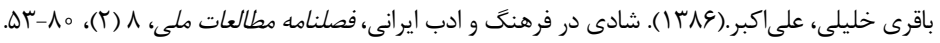

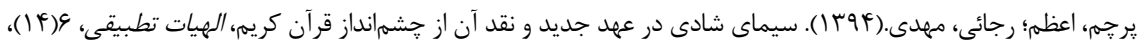
.

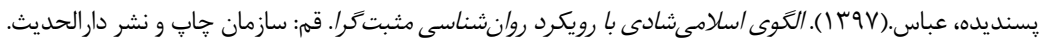

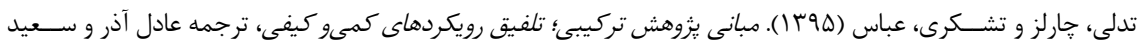

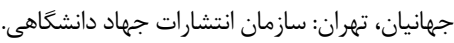

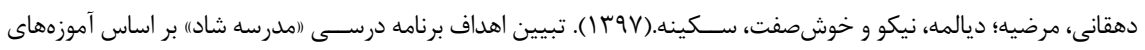

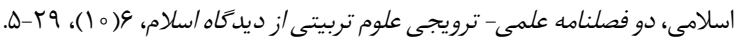

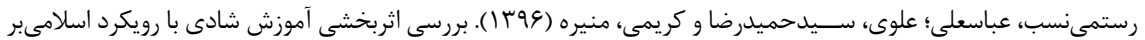

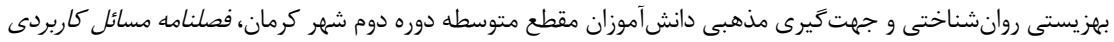
[Doi: qaiie.2.4.47/10.29252]

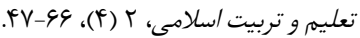

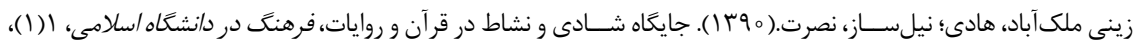

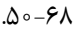

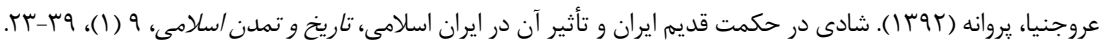

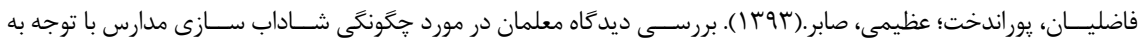

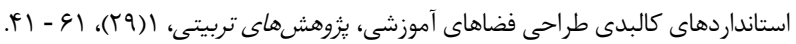

كرسول، جان دبليو.(1) (1). طرح يزوهش؛ رويكردهاى كيفى، كمىو تركيبى. ترجمه ع كيامنش و م دانايطوس. تهران:

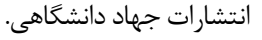

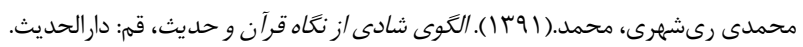

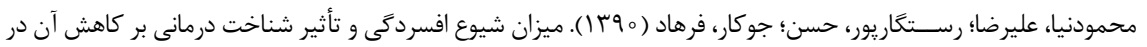

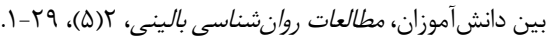

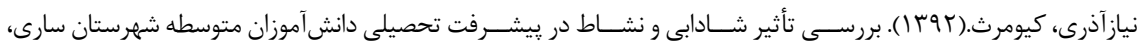

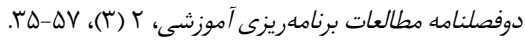

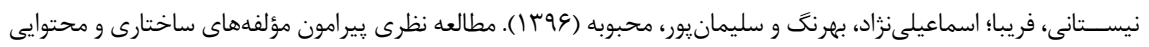

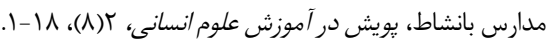

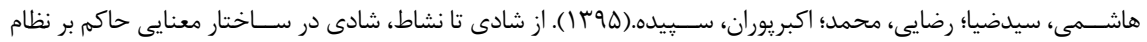

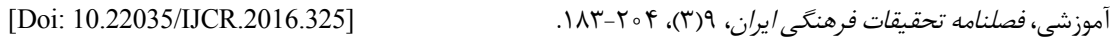

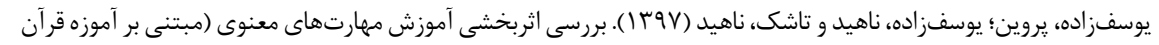

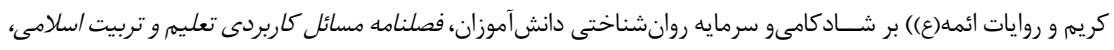


Anderson, R. C., Coates, K., Gearin, B., \& Zhao, Y. (2015). Counting what counts: Reframing education outcomes, Indiana, Solution Tree Press.

Attride - Stirling, J. (2001). Thematic networks: an analytic tool for qualitative research, Qualitative Research, 1(3), 385-405.

Helliwell, J. F., Huang, H., \& Wang, S. (2015). The geography of world happiness, World Happiness Report, 8, 12-41.

Kim, G. (2016). Happy Schools! A framework for learner well-being in the Asia-Pacific.UK: UNESCO Office Bangkok and Regional Bureau for Education in Asia and the Pacific.

Sherab, K. 2013. Gross national happiness education in Bhutanese schools: Understanding the experiences and efficacy beliefs of principals and teachers. Unpublished doctoral thesis. Australia: University of New England, Armidale.

Suldo, S. M. 2016. Promoting student happiness: Positive psychology interventions in schools. New York: Guilford Publications.

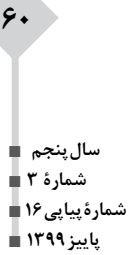

